\title{
MERCADO DE TÍTULOS DE DÍVIDA CORPORATIVA PRIVADA NO BRASIL: ASPECTOS ESTRUTURAIS E EVOLUÇÃO RECENTE ${ }^{(*)}(*)$
}

\author{
Luiz Fernando de Paula \\ João Adelino de Faria Jr2
}

RESUMO: Este artigo analisa fatores estruturais e conjunturais que impedem ou estimulam o crescimento do mercado de títulos corporativo de dívida privada (MTD) no Brasil, assim como avalia a evolução recente desse mercado a partir da estabilização de preços pós-1994 até o ano de 2008. Dois aspectos são privilegiados na análise realizada: a relação entre o MTD e a evolução do contexto macroeconômico, já que o comportamento da atividade econômica e da política econômica define o ambiente no qual o MTD cresce e reflui; e a relação entre o mercado de dívida pública e dívida privada corporativa no Brasil, que não tem sido na direção de complementaridade e sim de concorrência.

PALAVRAS-CHAVE: Mercado de capitais; mercado de títulos de dívida privada; dívida pública.

CLASSIFICAÇÃO JEL: E44; G11; G20.

\footnotetext{
*Artigo recebido em 23/02/2011 e aprovado em 20/05/2012.

${ }^{* *}$ Este artigo resulta de uma pesquisa realizada pelo UNICAMP/UFRJ/BNDES, sob a coordenação geral de Fernando Cardim de Carvalho e Ricardo Carneiro, intitulada "Perspectivas da indústria financeira brasileira e o papel dos bancos públicos".

${ }^{1}$ Doutor em Economia pelo Instituto de Economia da UNICAMP e professor titular da Faculdade de Ciências Econômicas da Universidade do Estado do Rio de Janeiro (FCE/UERJ) e pesquisador do CNPq. Contato: luizfpaula@terra.com.br.

${ }^{2}$ Mestre em Economia pela FCE/UERJ e pesquisador da Universidade do Estado do Rio de Janeiro (FCE/UERJ) e do CNPq (Auxílio à pesquisa). Contato: joao.adelino@hotmail.com.
} 


\title{
PRIVATE CORPORATE BONDS MARKET IN BRAZIL: STRUCTURAL FEATURES AND RECENT EVOLUTION
}

\begin{abstract}
The paper aims at analyzing the structural and circumstantial factors that obstruct or stimulate the development of private debt bond market in Brazil, as well as evaluate the recent evolution of this market since the price stabilization after 1994 until 2008. Two aspects are highlighted in the analysis: the relationship between the private debt bond market and the evolution of the macroeconomic context, as it defines the environment in which this market can grow or shrink; the relationship between the market of public debt and the corporate private debt in Brazil, the have not been complementary.
\end{abstract}

KEYWORDS: Capital markets; private debt bond markets; public debt. 


\section{INTRODUÇÃO}

Este artigo analisa fatores estruturais e conjunturais que impedem ou estimulam o crescimento do mercado de títulos corporativo de dívida privada (MTD) no Brasil, assim como avalia a evolução recente desse mercado a partir da estabilização de preços pós-1994 até o ano de 2008. A ênfase do artigo será dada ao mercado de debêntures, que, além de ser o título de dívida corporativa mais importante no Brasil, é o que possui mais informações e dados disponíveis.

O quadro referencial de análise aqui utilizado procura considerar os seguintes aspectos:

a) Contexto macroeconômico: a relação entre o MTD e a evolução do contexto macroeconômico, já que o comportamento da atividade econômica e da política econômica (em especial a política de juros) define o ambiente no qual o MTD cresce e reflui ${ }^{3}$.

b) Contexto institucional: de particular importância é importante entender a relação entre o mercado de dívida pública e dívida privada corporativa no Brasil, constituindo esta relação um aspecto estrutural de grande importância para o desenvolvimento do MTD privada.

O quadro referencial teórico de análise utilizado é a teoria da preferência pela liquidez, segundo o qual a demanda dos ativos financeiros não monetários é influenciada fundamentalmente pelo estado de expectativas dos agentes, sob condições de incerteza, que define as condições de retorno (ajustado ao risco) e de liquidez desses ativos ${ }^{4}$. Deste modo, quanto maior a incerteza percebida os agentes passam a valorizar os atributos de maior liquidez dos ativos em detrimento da rentabilidade, e com isso aumenta o prêmio de risco cobrado para aquisição de títulos de maior maturidade e/ou de baixa liquidez. Alternativamente, quanto menor a incerteza percebida, maior a propensão ao risco do investidor, sendo os atributos de rentabilidade privilegiados em relação à liquidez dos ativos financeiros. Tais “preferências” determinam não só a composição de portfólio dos agentes investidores como o prêmio de risco que cobram para adquirir ativos financeiros.

3 É importante destacar que no caso do MTD, ao contrário do mercado de ações brasileiro, o setor externo tem tido um papel limitado neste mercado, já que as aplicações de investidores externos são bem pequenas quando comparadas as aplicações em ações e em títulos públicos. O canal mais relevante é a emissão de títulos de empresas brasileiras no exterior, que atinge a valor médio de US\$20,6 bilhões em 2004/2007 (que a um câmbio de $\mathrm{R} \$ 1,80$ corresponde a $\mathrm{R} \$ 37,1$ bilhões), contra o valor médio de $\mathrm{R}$ 77,6 bilhões no mesmo período em termos de emissão de títulos corporativos no Brasil. 4 Ver, a respeito, Paula (1999) e Carvalho (2007). 
Um das implicações importantes dessa abordagem teórica para análise do MTD é que as condições de oferta de títulos corporativos são, em boa medida, determinadas pelo estado de expectativas dos agentes, que determina crucialmente a percepção de risco e retorno dos investidores. Como sugerido, o ambiente macroeconômico e a política econômica - crescimento da economia, inflação, política de juros, movimento da taxa de câmbio etc. - tem um papel fundamental na determinação da demanda e oferta por títulos e nas condições (montante emitido, remuneração, maturidade etc.) pelos quais os títulos são ou poderão ser emitidos. Do lado do ofertante de títulos corporativos (a empresa), o crescimento econômico (que aumenta a possibilidade de aumento de vendas e lucros, permitindo gerar renda para saldar compromissos financeiros assumidos) e o comportamento das taxas de juros (custo do crédito bancário e custo de oportunidade do capital) e de câmbio (preço fundamental na determinação das relações externas da empresa, por exemplo, para exportações e na determinação do custo de dívida externa) são fundamentais para definir a oferta de títulos. Do lado dos demandantes de títulos, além do ambiente macroeconômico em geral, a política de juros do banco central afeta de forma importante o grau de aversão a riscos dos investidores: uma expectativa de juros futuros elevados aumenta a preferência por moeda e ativos de alta liquidez, enquanto que uma expectativa de queda na taxa de juros futura aumenta a preferência por títulos de renda fixa ${ }^{5}$.

A existência de mercados secundários organizados para títulos privados também é um fator importante no desenvolvimento do mercado de títulos ao proporcionar maior liquidez aos ativos financeiros de maturidade mais longa e, com isso, podendo estimular (e no caso da ausência de mercados secundários, desestimular) a demanda por tais ativos. Por outro lado, deve-se considerar a relação entre dívida pública e dívida privada de empresas não financeiras, já que o desenvolvimento do primeiro permitiria o desenvolvimento do segundo, ao estabelecer uma infraestrutura necessária para a comercialização de títulos de dívida. Ao mesmo tempo o mercado de dívida pública pode estabelecer um benchmark para o mercado privado, ao permitir formar uma curva de rendimentos que contribua para identificar o custo de oportunidade de fundos para os investidores e poupadores.

\footnotetext{
${ }^{5}$ Considere que o agente tem dois ativos para aplicar seus recursos: moeda, que é um ativo seguro, e um título de renda fixa, que não é tão seguro, mas rende juros. Conforme a taxa de juros corrente está situada acima ou abaixo da taxa normal (i.e., a taxa de juros futura que o agente espera que prevaleça em um determinado horizonte temporal), os agentes procurarão vender ou comprar títulos: eles compram títulos quando esperam que seu preço suba (e os juros caiam) e os vende, obtendo dinheiro em contrapartida, quando esperam que o seu preço caia (os juros subam). Ver, a respeito, Carvalho et al. (2007).
} 
No caso do Brasil deve-se considerar algumas características peculiares do país, que têm implicações importantes do ponto de vista do desenvolvimento do MTD privada. Em primeiro lugar, o histórico de instabilidade macroeconômica que marcou a economia brasileira desde os anos 1980 é o fator principal na formação do perfil de dívida em curto prazo e com parcela significativa constituída por títulos atrelados à taxa Selic e a DI. As incertezas que têm cercado o comportamento da economia brasileira, caracterizado por ciclos de stop and go, tem sido grandes o suficiente para desestimular horizontes maiores de expectativas para investidores e empresas no país. Em segundo lugar, em que pese o elevado desenvolvimento do mercado de títulos públicos, a existência de uma boa parte da dívida pública sob a forma de títulos indexados a Selic - Letras Financeiras do Tesouro (LFTs), herança do período de alta inflação, acaba por inibir e deformar o MTD privada no Brasil, uma vez que a combinação risco-retorno dos títulos públicos é uma das melhores entre os ativos financeiros, por combinar baixo risco, alta liquidez e rentabilidade. Isso resulta em uma alta demanda por investimentos nos chamados fundos de depósitos interbancários (DI) ou diretamente por títulos públicos federais. Portanto, a forma de gestão da dívida pública no Brasil acaba sendo determinante nas "preferências" do investidor, ao moldar uma combinação riscoretorno que privilegia aplicações indexadas a taxa Selic e sua "prima" a taxa DI ou aplicações de renda fixa de curto prazo.

O artigo está dividido em quatro seções, além desta Introdução. A seção 2 analisa o contexto macroeconômico brasileiro recente e a relação entre dívida pública e dívida privada no Brasil. A seção 3, por sua vez, efetua um breve panorama das características e evolução do MTD a partir de 1995. A seção 4 conclui o artigo e apresenta algumas sugestões para o desenvolvimento do MTD no Brasil.

\section{CONTEXTO MACROECONÔMICO E RELAÇÃO ENTRE DÍVIDA PÚBLICA E DÍVIDA PRIVADA}

\subsection{BREVE CONTEXTUALIZAÇÃO MACROECONÔMICA}

Desde o começo dos anos 1980 a economia brasileira vem apresentando um crescimento baixo e volátil: entre 1981 e 2008 a média do crescimento do PIB foi de 2,6\%, contrastando com o crescimento médio de 7,1\% entre 1947 e 1980, durante o período de industrialização por substituição de importações (ISI). O baixo crescimento entre 1990 e 2008 foi resultado do fenômeno de alta inflação (até 1994), de uma elevada vulnerabilidade externa e também dos efeitos de uma elevada taxa de juros real (cerca de $11 \%$ no período 1990-2006). De fato, as taxas de investimento tem se mantido baixa durante anos, menos do que 20\% do PIB desde 1996 contra uma taxa de investimento de cerca de $25 \%$ nos anos 1970. Esses resultados contrastam com o dinamismo de 
outras economias emergentes de maior porte, como China e Índia, que tiveram um crescimento, respectivamente, de $10 \%$ a.a. e 6,4\% no período $1990-2007^{6}$.

O Gráfico 1 mostra o comportamento a la stop and go que tem caracterizado a economia brasileira nos últimos anos: curtos ciclos de crescimento são seguidos de uma desaceleração econômica. Os períodos de maior crescimento do MTD privada, como 1994-1995 e 2004-2007, coincidem, grosso modo, com períodos de maior crescimento econômico, uma vez que é de se esperar que as firmas busquem novas fontes de financiamento para expansão de suas atividades durante as fases de crescimento da renda e do produto. Isso parece evidenciar a importância que um ambiente de crescimento econômico mais duradouro e de maior estabilidade macroeconômica pode ter sobre o desenvolvimento do MTD privada. Uma diferença importante entre o período 1994-1995 e o período 2004-2007 é que no primeiro, no contexto de um processo de estabilização de preços com um câmbio semifixo, as taxas reais de juros eram extremamente elevadas, enquanto que no segundo houve uma redução nessas taxas, mas que ainda se mantiveram em patamares elevados, considerando que a política econômica passou a ser operada com um regime de câmbio flutuante a partir de 1999 (Tabela 1).

\section{Gráfico 1 - Taxa de crescimento do PIB real (\%)}

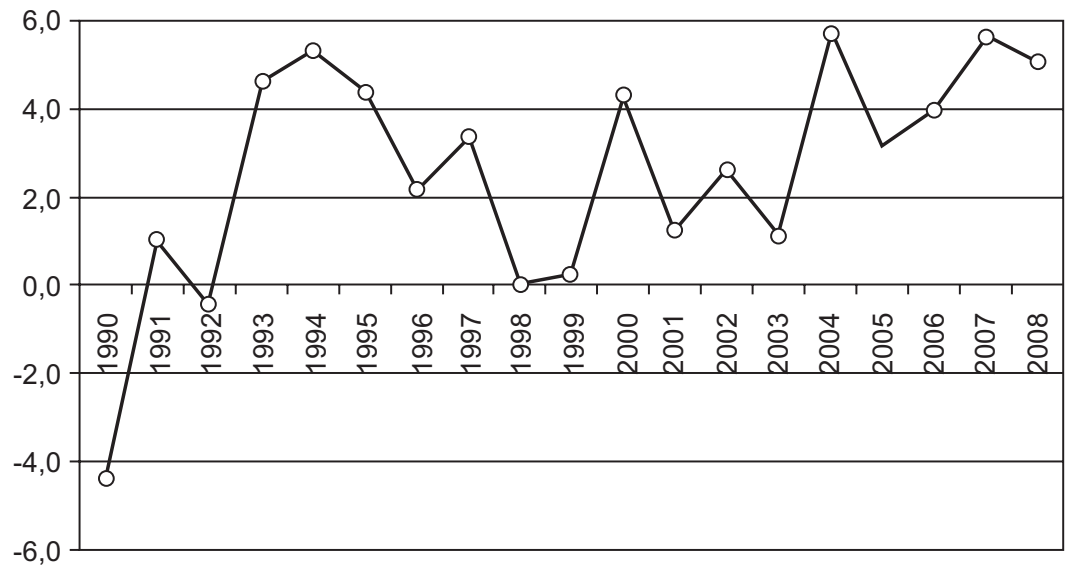

Fonte: IPEADATA (2009).

${ }^{6}$ Conforme dados do International Financial Statistics do FMI. 


\begin{tabular}{|c|c|c|c|c|c|c|c|c|c|c|c|c|c|c|c|}
\hline $\begin{array}{l}\infty \\
\text { ¿ें }\end{array}$ & $\overrightarrow{i n}$ & $\stackrel{\circ}{\approx}$ & के & हे & $\stackrel{\leftrightarrow 2}{\rightarrow}$ & $\begin{array}{l}\infty \\
\infty \\
\infty \\
\infty\end{array}$ & $\stackrel{\infty}{\infty}$ & 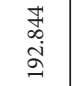 & $\stackrel{m}{i}$ & $\stackrel{m^{2}}{\exists}$ & ڤે & $\stackrel{H}{\rightarrow}$ & $\begin{array}{l}\stackrel{2}{\stackrel{2}{2}} \\
\stackrel{\sim}{\sim}\end{array}$ & 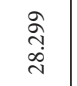 & \\
\hline ڤ્సે & is & $\stackrel{2}{\stackrel{2}{二}}$ & $\stackrel{\text { in }}{f}$ & $\dot{0}_{0}^{\infty}$ & $\overrightarrow{\hat{\imath}}$ & $\begin{array}{l}\hat{f} \\
\hat{f}\end{array}$ & $\stackrel{\stackrel{n}{\prime}}{\approx}$ & 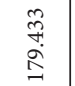 & $\overrightarrow{0}$ & 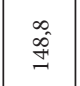 & $\stackrel{m}{\infty^{2}}$ & $\stackrel{n}{\rightarrow}$ & $\begin{array}{l}\vec{m} \\
\stackrel{\leftrightarrow}{\dot{q}}\end{array}$ & 员 & \\
\hline ఫ̊ڤ & $\stackrel{\circ}{\rightarrow}$ & $\stackrel{\overrightarrow{0}}{\stackrel{H}{0}}$ & $\vec{m}$ & $\stackrel{\circ}{=}$ & $\hat{\hat{\imath}}$ & $\stackrel{0}{f}$ & $\stackrel{\infty}{\vec{\sim}}$ & $\begin{array}{l}\vec{b} \\
\stackrel{n}{\infty} \\
\infty \\
\infty\end{array}$ & $\cong$ & బิ & $\begin{array}{l}6 \\
\infty \\
\infty\end{array}$ & $\stackrel{H}{\rightarrow}$ & 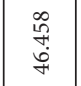 & $\begin{array}{l}\text { ఫ్రి } \\
\text { త్ర }\end{array}$ & \\
\hline 䓂 & $\stackrel{\sim}{m}$ & ڤิ & $\hat{i n}$ & $\Rightarrow$ & $\stackrel{\infty}{\stackrel{\infty}{i}}$ & $\begin{array}{l}\text { जी } \\
\text { ố }\end{array}$ & $\stackrel{\mathscr{P}}{i}$ & $\begin{array}{l}\stackrel{\mathscr{H}}{\mathrm{H}} \\
\underset{n}{n}\end{array}$ & $\stackrel{n=}{=}$ & $\hat{N}$ & $\stackrel{m}{\vec{v}}$ & $\stackrel{0}{\sim}$ & $\begin{array}{l}\stackrel{2}{2} \\
\stackrel{+}{+}\end{array}$ & 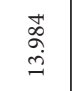 & \\
\hline 总 & $\hat{n}$ & $\overrightarrow{0}$ & $\stackrel{\circ}{\sim}$ & $\stackrel{20}{N}$ & $\stackrel{m}{i}$ & $\begin{array}{l}\stackrel{2}{f} \\
\stackrel{f}{4}\end{array}$ & $\stackrel{\text { }}{\hat{i}}$ & $\begin{array}{l}\text { ర్ } \\
\text { i } \\
\text { in }\end{array}$ & $\stackrel{0}{-}$ & $\begin{array}{l}\mathscr{n}^{2} \\
\infty^{2}\end{array}$ & $\mathrm{~m}^{1}$ & $\stackrel{m}{i}$ & $\begin{array}{l}: \\
\stackrel{0}{0} \\
\aleph^{\circ}\end{array}$ & $\stackrel{\infty}{\stackrel{\infty}{=}}$ & \\
\hline ڤ̊̊̊ & $\Rightarrow$ & $\hat{n}^{2}$ & $\sigma^{2}$ & $\Rightarrow$ & $\stackrel{m}{\rho}$ & $\hat{\tilde{n}}$ & $\begin{array}{c}\infty \\
\stackrel{\infty}{m} \\
n^{2}\end{array}$ & $\begin{array}{l}\text { f } \\
\infty \\
\infty \\
\infty \\
\stackrel{d}{+}\end{array}$ & $\hat{o}$ & $\stackrel{1}{=}$ & $\begin{array}{l}\hat{L} \\
\tilde{f}\end{array}$ & $\stackrel{\vec{m}}{m}$ & 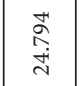 & $\stackrel{\curvearrowright}{\stackrel{ }{\rightleftarrows}}$ & \\
\hline ఫેّ & $\hat{i}$ & $\stackrel{H}{6}$ & $\stackrel{n}{\mathfrak{y}}$ & $\vec{n}$ & $\vec{a}$ & in & ๙ે & 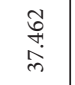 & $\stackrel{\infty}{\rightarrow}$ & $\hat{\gamma}^{2}$ & $\vec{f}$ & $\stackrel{\infty}{\kappa^{\circ}}$ & $\begin{array}{l}\vec{T} \\
\stackrel{\vec{J}}{\rightarrow}\end{array}$ & $\underset{\hat{\sigma}}{\hat{i}}$ & $\begin{array}{l}\stackrel{\widehat{0}}{\tilde{E}} \\
\vec{y} \\
\vec{x}\end{array}$ \\
\hline$\overline{\text { ¿े }}$ & $\stackrel{m}{\rightarrow}$ & $\stackrel{\circ}{\stackrel{1}{-}}$ & $\hat{\therefore}$ & $\stackrel{+}{\infty}$ & $\stackrel{\infty}{+}$ & $\begin{array}{l}\stackrel{H}{\prime} \\
\stackrel{\alpha}{q}\end{array}$ & $\stackrel{\stackrel{m}{m}}{i}$ & 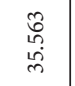 & $\vec{f}$ & $\begin{array}{l}\text { 앙 } \\
\text { +े }\end{array}$ & $\begin{array}{l}\infty \\
\hat{q}\end{array}$ & $\vec{m}$ & $\begin{array}{l}8 \\
\qquad 0 \\
i \\
i\end{array}$ & 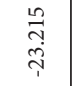 & $\begin{array}{l}\frac{3}{0} \\
0 \\
0 \\
0 \\
0\end{array}$ \\
\hline ఫે & $\stackrel{m}{\sim}$ & $\overrightarrow{ \pm}$ & $\dot{0}$ & $\stackrel{\sim}{\varrho}$ & $\stackrel{n}{f}$ & $\begin{array}{l}\stackrel{2}{2} \\
\stackrel{2}{f}\end{array}$ & $\stackrel{\infty}{\sim}$ & $\begin{array}{l}\stackrel{H}{+} \\
\underset{j}{i}\end{array}$ & $\stackrel{\circ}{\stackrel{f}{i}}$ & $\overrightarrow{\hat{\infty}^{n}}$ & $\begin{array}{l}0 \\
\delta_{n}^{\circ}\end{array}$ & $\stackrel{m}{\sim}$ & 㫣 & 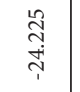 & $\begin{array}{l}\frac{2}{0} \\
\frac{\pi}{0} \\
\frac{2}{2}\end{array}$ \\
\hline ڤे & $m_{0}^{m}$ & $\begin{array}{l}\stackrel{2}{2} \\
\stackrel{2}{n}\end{array}$ & के & $\vec{\exists}$ & $\stackrel{0}{\stackrel{0}{1}}$ & $\stackrel{10}{f}$ & $\underset{\rightarrow \infty}{\rightarrow}$ & $\begin{array}{l}\text { 今ે } \\
\text { Wn }\end{array}$ & $\stackrel{m}{+}$ & $\stackrel{\sigma^{\prime}}{\stackrel{n}{n}}$ & $\stackrel{ }{=}$ & in & 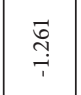 & 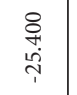 & $\begin{array}{l}\frac{5}{2} \\
\text { o } \\
\frac{\pi}{\pi} \\
\frac{\pi}{7}\end{array}$ \\
\hline $\begin{array}{l}\infty \\
\text { పे }\end{array}$ & : & $\hat{\overbrace{}}$ & $\approx$ & خे & $\hat{i}$ & $\stackrel{\hat{\infty}}{\stackrel{m}{ }}$ & $\stackrel{\sim}{=}$ & 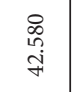 & $\stackrel{f}{f}$ & $\hat{n}$ & $\begin{array}{l}0 \\
\infty \\
\stackrel{N}{N}\end{array}$ & $\stackrel{f}{f}$ & $\begin{array}{l}\text { 客 } \\
\text { i. }\end{array}$ & 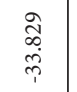 & 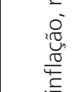 \\
\hline ڤे & $\stackrel{H}{m}$ & $\hat{\sigma}$ & in & $\vec{\Xi}$ & $\overrightarrow{0}$ & $\stackrel{\infty}{\hat{m}}$ & $\Rightarrow$ & $\begin{array}{l}\text { A } \\
\infty \\
0 \\
i n\end{array}$ & ले & $\underset{+}{\stackrel{\infty}{0}}$ & $\hat{\tilde{\lambda}}$ & $\stackrel{\infty}{\infty}$ & $\begin{array}{l}\text { గ్రి } \\
0 \\
1\end{array}$ & 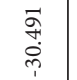 & \\
\hline よ̊ & $\tilde{\mathrm{i}}$ & $\tilde{a}^{2}$ & $\stackrel{\circ}{a}$ & छे & फे & $\hat{\hat{p}^{\prime}}$ & $\stackrel{\circ}{\rightarrow}$ & $\begin{array}{l}\tilde{1} \\
\infty \\
\infty \\
i\end{array}$ & $\vec{p}$ & 茴 & $\stackrel{+}{\vec{N}}$ & $\overbrace{}^{\infty}$ & 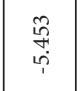 & $\begin{array}{l}\stackrel{\infty}{d} \\
\underset{\sim}{\sim} \\
\end{array}$ & 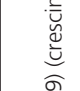 \\
\hline ڤ̊ & $\stackrel{H}{f}$ & $\begin{array}{l}\text { nn } \\
\stackrel{\text { in }}{2}\end{array}$ & $\stackrel{\vec{N}}{\hat{d}}$ & $\hat{\vec{N}}$ & $\stackrel{m}{i}$ & $\begin{array}{l}0 \\
\stackrel{\infty}{\sim}\end{array}$ & $\hat{\partial}$ & 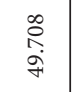 & $\hat{i}$ & $\overrightarrow{8}$ & $\hat{\hat{i}}$ & $\stackrel{H}{m}$ & $\stackrel{\hat{n}}{\stackrel{n}{r}}$ & $\begin{array}{l}\infty \\
\substack{7 \\
\infty \\
1}\end{array}$ & 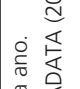 \\
\hline & 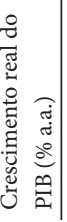 & 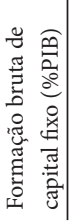 & 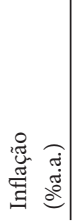 & 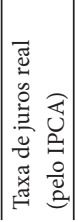 & 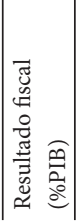 & 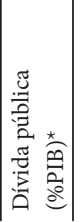 & 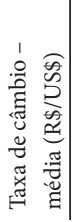 & 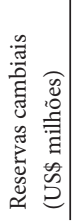 & 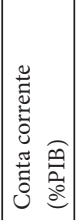 & 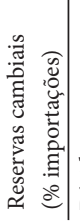 & 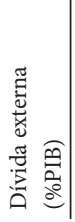 & 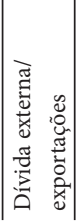 & 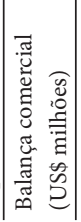 & 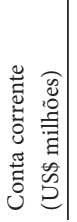 & 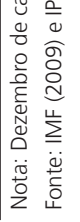 \\
\hline
\end{tabular}


Após a crise cambial de janeiro de 1999, resultante, entre outros fatores, da elevada vulnerabilidade externa do país (déficit em conta corrente de 4,0\% do PIB em 1998), o Brasil adotou um novo modelo de política econômica, baseado nas seguintes características: regime de câmbio flutuante, sistema de metas de inflação e geração de constantes superávits primários, que resultaram em taxas de juros menores que no período anterior (1995-1998), porém, ainda alta. Ademais, o modus operandi do sistema de metas de inflação, somado ao regime de câmbio flutuante e operando sob condições de abertura (quase) total da conta de capital, resultou em grande instabilidade da taxa de câmbio nominal. A volatilidade da taxa de câmbio evidentemente é maior em momentos de saída de capitais do país, como ocorreu em 2002-2003 e em 2008, como pode ser visto no Gráfico 2. Nota-se, contudo, que a taxa DI - que é a taxa definida no mercado interbancário, e que guarda uma forte vinculação com a taxa básica de juros Selic - é também bastante volátil. A taxa DI é importante para o MTD privada, pois nos anos 2000 tem sido o principal indexador dos principais títulos de dívida privada e de instrumentos de securitização, como debêntures e FIDC.

Gráfico 2 - Volatilidade do câmbio e da taxa DI

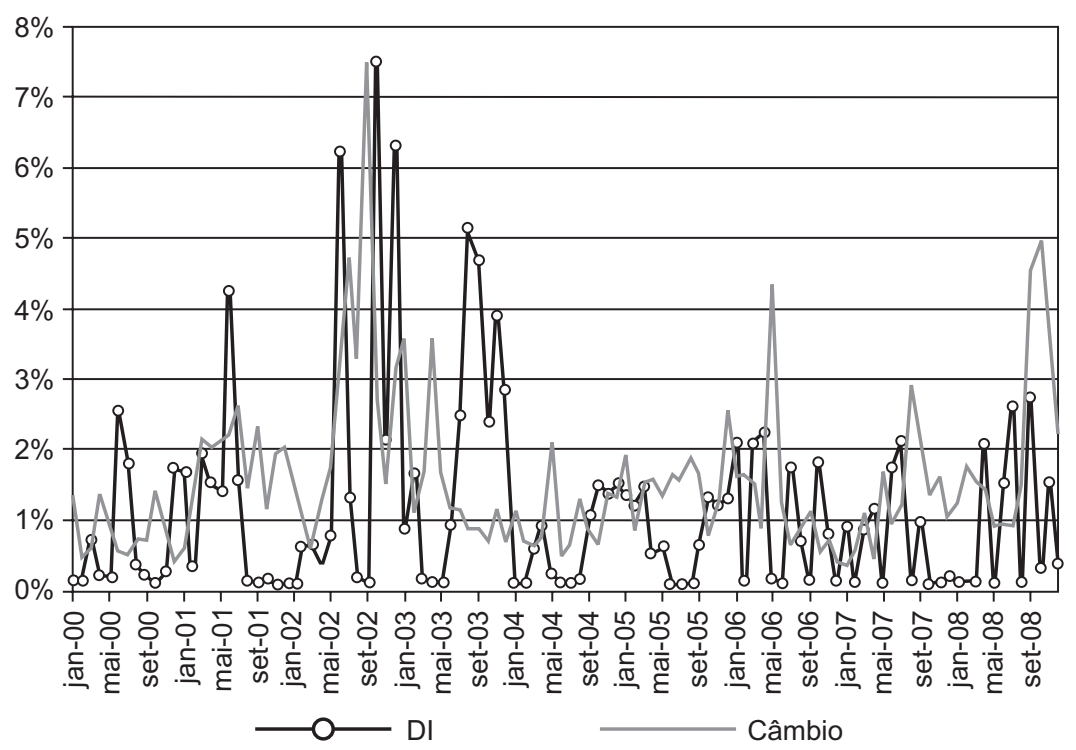

Nota: Volatilidade calculada com base no coeficiente de variação.

Fonte: Elaboração própria com base em BCB (2009).

O ambiente de instabilidade macroeconômica de uma economia em stop and go têm afetado o volume e as condições de emissão primária de títulos de dívida privada no Brasil, ao aumentar o risco de mercado (perda de valor de um título perante a uma 
elevação na taxa de juros) e o risco de inadimplência na emissão de tais títulos, em particular no caso de títulos corporativos de renda fixa. De modo geral, a operação da política monetária após a adoção do regime de metas de inflação no Brasil tem se caracterizado pelo conservadorismo, que gera frequentemente, a qualquer sinal de um aumento no crescimento econômico (e na demanda agregada), expectativas de aumento na taxa básica de juros por parte do Banco Central para controlar a inflação ${ }^{7}$. A presença de expectativas altistas quanto à taxa de juros eleva o prêmio exigido pelos demandantes por títulos de maturidade mais longa, em particular se o aumento de juros se confirma e se mantém por um período longo (Hermann, 2003), ou alternativamente aumenta a demanda por títulos indexados a DI, que embute um risco de taxa de juros nulo. Sob essas condições, os investidores mantêm sua preferência pela liquidez aguçada, ao mesmo tempo em que procuram, ao aplicarem em títulos de maturidade mais longa, se prevenir do risco de mercado, demandando para tanto títulos indexados. Em outras palavras, os agentes demandam títulos de dívida (pública ou privada) prefixados de curto prazo e de alta remuneração (notas promissórias, CDBs pré, LTNs, NTNs-F etc.) ou títulos públicos indexados a Selic de médio prazo e remuneração mais baixa que os títulos pré, ou ainda títulos de maturidade mais longa indexados a DI (debêntures-DI, FIDC, CDBs pós etc.) ou a inflação (debêntures indexadas a inflação, NTN-B e NTN-C). Sob tais condições a emissão de títulos prefixados, inclusive títulos públicos (que não tem risco de default), de maturidade mais longa, fica quase que completamente inviabilizada, pois sua colocação iria requerer a incorporação de um prêmio de risco extremamente elevado na remuneração do título ${ }^{8}$.

\subsection{RELAÇÃO ENTRE DÍVIDA PÚBLICA E DÍVIDA PRIVADA: COMPLEMENTARIDADE OU COMPETIÇÃO?}

Frequentemente tem sido destacado na imprensa especializada que o estoque de papéis privados tem se igualado ao estoque de títulos públicos no Brasil, em função do forte crescimento ocorrido no MTD privada em 2008 e 20099. Contudo, o crescimento de títulos de dívida privada no período foi determinado fundamentalmente pelo crescimento das CDBs, títulos emitidos pelos bancos em um momento em

\footnotetext{
${ }^{7}$ Modenesi (2008) mostra evidências de que a formação da taxa Selic é pautada por uma convenção próconservadorismo na condução da política monetária, com um comportamento assimétrico do BCB que eleva mais fortemente a taxa de juros por ocasião de aumento no hiato do produto e/ou no hiato inflacionário, e reduzindo pouco quando diminui tais hiatos.

${ }^{8}$ Retornamos a este ponto na próxima seção.

${ }^{9}$ Ver, por exemplo, a reportagem Estoque de papéis empata com títulos públicos, Valor (24/06/2009).
} 
que houve certo "empoçamento" de liquidez no mercado interbancário. Quando se compara o crescimento do estoque de títulos públicos federais com o estoque de títulos de dívida corporativa doméstica, a diferença entre os dois tipos de títulos é significativa. Ademais, o Gráfico 3 mostra que parece não haver no Brasil uma relação de causalidade mais definida entre títulos públicos e títulos corporativos no Brasil, não havendo evidências de que o crescimento do mercado de títulos públicos venha estimulando o crescimento do mercado de títulos corporativos.

\section{Gráfico 3 - Estoque de títulos públicos federais (TPF) e títulos de dívida privada (TDP)}

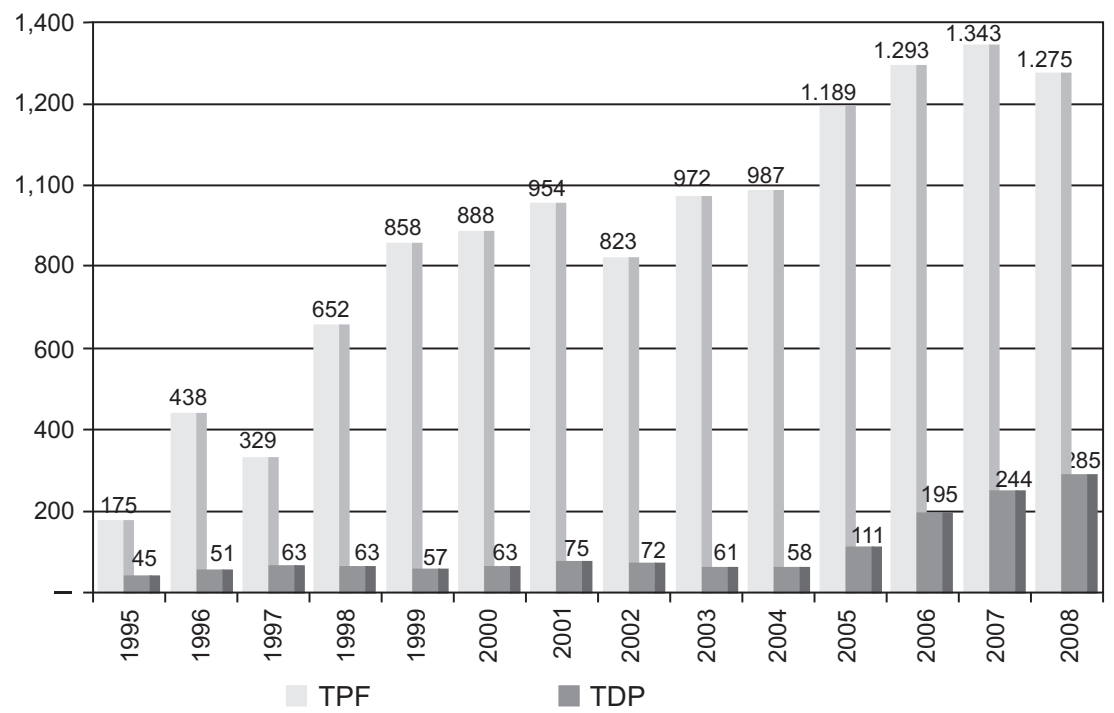

Nota: Consideram-se apenas os títulos corporativos. Valores em bilhões de reais de dez/2008. Fonte: STN (2009) para TPF e CETIP (2009) para TDP.

Em realidade, não apenas parece não haver complementaridade entre os dois mercados, como parece haver evidências da existência de concorrência entre os mesmos. As condições vantajosas oferecidas pelos títulos públicos federais indexados a variáveis mais voláteis do mercado - taxa de juros, taxa de câmbio e/ou taxa de inflação - ao mesmo tempo em que oferece ao demandante de título uma proteção contra os riscos de juros, cambial ou de perda inflacionária, lhe proporciona papéis que combinam rentabilidade, liquidez e baixo risco. A Tabela 2 mostra a estrutura da dívida pública federal no Brasil por indexador: até 2005 os títulos indexados a Selic (LFTs) respondiam por mais de $50 \%$ do estoque de títulos públicos, sendo que apenas a partir de 2006 reduz sua participação, alcançando um patamar ao redor de 35\% em 2007/2008. A política de alongamento de dívida através da emissão de 
títulos pré-fixados foi estimulada, em certa medida, pelo otimismo propiciado pela perspectiva de queda de inflação e de redução na taxa básica de juros a partir de meados de 2003 (Ferreira et al., 2004).

Tabela 2 - Estrutura da dívida pública por indexador (\% do total)

\begin{tabular}{l|c|c|c|c|c|c|c|c}
\hline Data & Câmbio & TR & IGP & Selic & Prefixado & IPC-A & Outros & Total \\
\hline jun/00 & 21,1 & 5,4 & 5,4 & 54,7 & 13,3 & 0,0 & 0,1 & 100,0 \\
\hline dez/00 & 22,3 & 4,7 & 5,9 & 52,2 & 14,8 & 0,0 & 0,1 & 100,0 \\
\hline jun/01 & 26,8 & 5,0 & 7,2 & 50,2 & 10,8 & 0,0 & 0,0 & 100,0 \\
\hline dez/01 & 28,6 & 3,8 & 7,0 & 52,8 & 7,8 & 0,0 & 0,0 & 100,0 \\
\hline jun/02 & 29,9 & 2,2 & 7,5 & 50,4 & 8,6 & 1,4 & 0,0 & 100,0 \\
\hline dez/02 & 22,4 & 2,1 & 11,0 & 60,8 & 2,2 & 1,6 & 0,0 & 100,0 \\
\hline jun/03 & 13,5 & 2,0 & 11,3 & 67,2 & 4,5 & 1,6 & 0,0 & 100,0 \\
\hline dez/03 & 10,8 & 1,8 & 11,2 & 61,4 & 12,5 & 2,4 & 0,0 & 100,0 \\
\hline jun/04 & 8,9 & 1,8 & 11,9 & 57,5 & 16,8 & 3,0 & 0,0 & 100,0 \\
\hline dez/04 & 5,2 & 2,7 & 11,8 & 57,1 & 20,1 & 3,1 & 0,0 & 100,0 \\
\hline jun/05 & 3,6 & 2,5 & 10,6 & 57,1 & 23,0 & 3,3 & 0,0 & 100,0 \\
\hline dez/05 & 2,7 & 2,1 & 8,2 & 51,8 & 27,9 & 7,4 & 0,0 & 100,0 \\
\hline jun/06 & 2,3 & 2,0 & 7,7 & 42,5 & 31,5 & 14,1 & 0,0 & 100,0 \\
\hline dez/06 & 1,3 & 2,2 & 7,2 & 37,8 & 36,1 & 15,3 & 0,0 & 100,0 \\
\hline jun/07 & 1,1 & 2,3 & 6,4 & 34,1 & 38,7 & 17,5 & 0,0 & 100,0 \\
\hline dez/07 & 1,0 & 2,1 & 6,5 & 33,4 & 37,3 & 19,8 & 0,0 & 100,0 \\
\hline jun/08 & 0,8 & 2,1 & 5,7 & 34,5 & 34,8 & 22,2 & 0,0 & 100,0 \\
\hline dez/08 & 1,1 & 1,6 & 5,7 & 35,8 & 32,2 & 23,6 & 0,0 & 100,0 \\
\hline
\end{tabular}

Fonte: Elaboração própria com base em Banco Central do Brasil (2009).

Os títulos indexados ao câmbio, por sua vez, tiveram uma participação importante no total da dívida pública até 2002, quando atingiram em junho $30 \%$ do total, declinando sua participação a partir daí, até ter uma participação de cerca de $1 \%$ na estrutura da dívida pública. Os títulos prefixados (LTNs) cresceram sua participação relativa a partir de 2004, alcançando em 2006 mais de 30\% da dívida pública. Por fim, observa-se certa troca de títulos indexados ao IGP (NTN-C) por títulos indexados ao IPCA (NTN-B) a partir de 2006. De fato o IGP é um índice mais sensível ao comportamento da taxa de câmbio, e, deste modo, a tendência à valorização cambial, e consequente expectativa de uma queda do IGP em relação ao IPCA, estimulou a demanda pelas NTN-B. Os títulos indexados a inflação - que pagam também uma taxa de juros real - são particularmente demandados por fundos de pensão, que procuram uma proteção à inflação em suas aplicações. Observa-se, assim, que após uma piora na composição da dívida pública até 2003, houve uma melhoria na sua estrutura, em um contexto em que o ambiente macroeconômico ficou relativamente mais estável, destacando em particular a forte redução dos títulos indexados ao câmbio e o aumento dos prefixados. Em que pese a 
redução relativa dos títulos indexados a Selic (LFTs), esses ainda compõem mais de 1/3 do total da dívida pública.

A maior deformação na dívida pública brasileira é a existência de títulos públicos indexados a Selic - as chamadas LFTs -, criadas no auge do Plano Cruzado para diminuir a vulnerabilidade do sistema financeiro às mudanças na política monetária. Tal título tem a característica de ter duration zero. Duration é o tempo em que o capital retorna ao investidor para que este possa se reposicionar perante a nova taxa de juros de mercado ${ }^{10}$. A duration da LFT é de um dia ou zero, dado que o título remunera o valor aplicado pela taxa de juros a cada dia, ou seja, é como se o investidor estivesse a cada dia (durante todo o prazo do título) reaplicando o principal e o juro ganho à nova taxa de juros de mercado. Para o demandante do título público, isto significa não haver risco de taxa de juros na detenção desse título, risco este que fica a cargo do emissor (Tesouro Nacional). O investidor tem, em princípio, a alternativa de resgatar a dívida no dia a dia, possuindo assim a garantia de liquidez imediata ${ }^{11}$. A recontratação do preço da LFT se realiza na prática em bases diárias, pela taxa média do Sistema Especial de Liquidação e de Custódia, que é apurada pelo BCB com base nos preços de negociação de todos os títulos públicos federais no mesmo dia, havendo assim uma precificação diária (Moura, 2006, p. 247-248). No outro extremo, temos os títulos prefixados, como as LTNs e as NTN-F, que têm a duration igual ao seu prazo de vencimento, isto é, apenas ao final desse prazo pode o investidor se posicionar perante às mudanças na taxa de juros. Um detentor de um título prefixado sofre perdas por ocasião de uma elevação na taxa de juros, o que não acontece com o detentor de um título indexado a Selic. Assim, as LFTs protegem o investidor do risco de mercado, já que mudanças nas taxas de juros podem ocorrer de forma gradual ou em razão de choques externos imprevistos na economia. Isso não quer dizer que tais títulos não possam ter sua remuneração reduzida ante os outros títulos prefixados ou indexados a outras variáveis, como de fato acontece por ocasião de uma redução na taxa Selic. O que os torna atraentes é a possibilidade de reposicionamento diário ante a taxa de juros, o que permite um hedge contra choques imprevistos na taxa de juros, além - e não menos importante - do benefício de taxas de juros nominal e real generosas, como pode ser visto na Tabela 1 estas variaram de 5 a 12\% em 2000-2008.

A existência de títulos indexados a taxa Selic acaba por contaminar a emissão primária de títulos de dívida privada com a lógica de overnight ${ }^{12}$. Mais especificamente,

\footnotetext{
${ }^{10}$ Para maiores detalhes, ver Anexo I.

${ }^{11}$ Deve-se assinalar que a transformação diária das LFTs em depósitos a vista não é feita sem custos para os detentores de títulos, já que o BCB aplica taxas punitivas aos agentes com excesso ou falta de reservas.

${ }^{12}$ Este ponto é destacado por Franco (2006), ainda que sua interpretação sobre a relação entre dívida pública e dívida privada seja diferente da que é feita neste trabalho, uma vez que entendemos que não há um efeito crowding out no mercado de títulos de dívida como sugere este autor.
} 
as LFTs influenciam as condições de emissão dos TDP, em função do fato de que tais títulos: (i) como qualquer outro título público, tem risco de default praticamente nulo, por serem garantidos pelo Tesouro; (ii) especificamente, no caso das LFTs é o único título de dívida livre do risco de mercado, por não sofrer apreciação/depreciação em seu preço - ou seja, não têm embutido como qualquer título prefixado um risco de mercado; (iii) como se não bastasse, tais títulos têm oferecido taxas de remuneração elevadas, ainda que inferiores aos títulos prefixados, em função da política de juros altos que tem sido praticada pelo $\mathrm{BCB}$, mesmo sob o regime de metas de inflação.

O Gráfico 4 mostra o prazo médio e a duração média da dívida pública federal de 1997 a 2008. Até meados de 1998, prazo e duration coincidiam em função da predominância de títulos prefixados, ainda que com prazo muito curto (não mais do que 7 meses). A partir de então o crescimento de títulos públicos indexados, em particular as LFTs, faz com que se alongue o prazo da dívida, mas ao mesmo tempo aumente a diferença entre prazo e duration médios. A duration média da dívida pública foi inferior a um ano até início de 2006, por conta da predominância das LFTs na composição da dívida pública. A diminuição na emissão de títulos públicos indexados a Selic (e aumento das emissões de títulos prefixados) a partir de 2006, acompanhado por um concomitante aumento no prazo médio dos títulos públicos, fez com que essa diferença diminuísse substancialmente, ao mesmo tempo em que aumentou a duration média da dívida pública de cerca de 1 ano para mais de 2 anos. Em 2008, entretanto, observa-se uma estagnação no alongamento da duration média. A dominância de uma dívida pública com baixa duration tem implicações importantes para emissão de títulos de dívida privada, já que dificulta sobremaneira a oferta de títulos prefixados com prazos relativamente longos.

Portanto, as características das LFTs acabam por contaminar a emissão primária de títulos de dívida privada ao serem um forte concorrente a esses. Nesse contexto, para serem emitidos títulos corporativos prefixados de maturidade mais longa, estes teriam que pagar um prêmio de risco extremamente elevado para compensar a sua baixa liquidez, seu maior risco de mercado (ante a baixa duration dos títulos públicos) e maior risco de default, o que tornaria muito cara e/ou com maturidade muito curta sua emissão, fato este incompatível com a rentabilidade no negócio de uma firma produtiva. Nesse contexto, os emissores de títulos de dívida privada passam a ter duas opções: (i) emissão de títulos de dívida privada prefixados com alta remuneração e prazo curto (por exemplo, notas promissórias); (ii) emissão de debêntures de remuneração média e prazo médio (assim como FIDC), mas com características relativamente semelhantes as LFT (remuneração vinculada à taxa DI e duration nula, isto é, sem risco de mercado), mas ainda assim com um prêmio de risco maior do que essas. O Gráfico 5 mostra as taxas de remuneração das debêntures indexadas a DI, que pagam uma percentagem da DI ou a taxa DI mais um spread. 


\section{Gráfico 4 - Prazo e duração média da dívida pública federal (mês)}

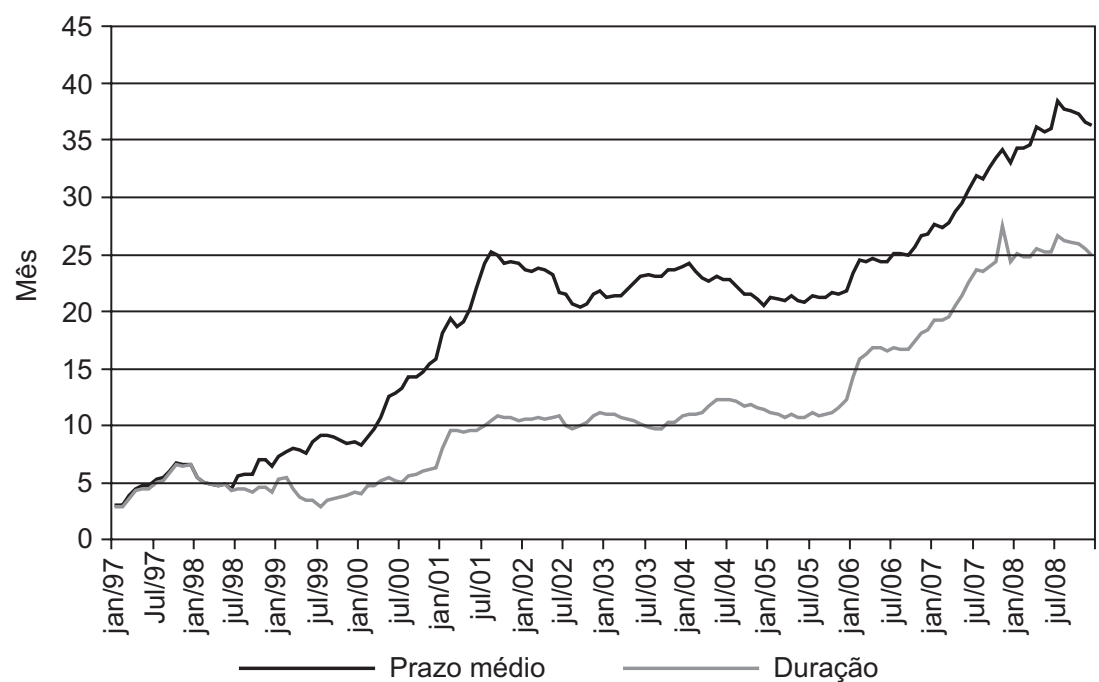

Fonte: Banco Central do Brasil (2009).

\section{Gráfico 5 - Taxa DI e taxa DI-Debêntures (\% a.a.)}

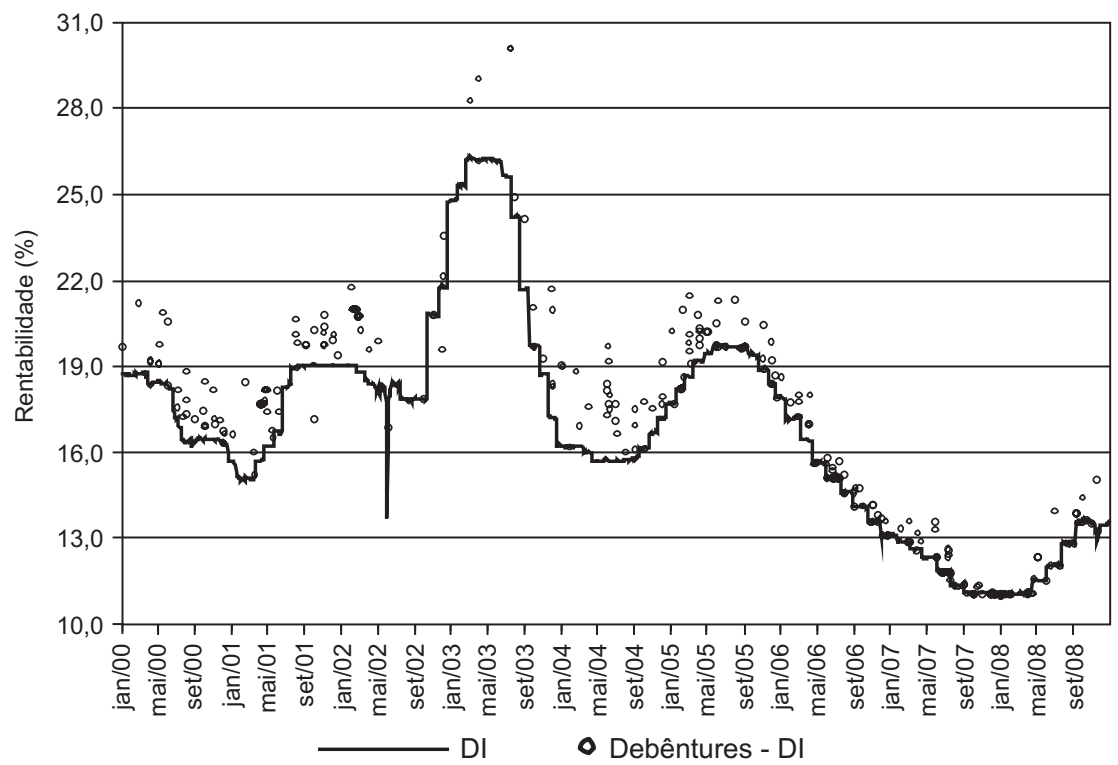

Fonte: Elaboração própria com base em Banco Central do Brasil (2009)

e Sistema Nacional de Debêntures (2009). 
O emissor de títulos indexados a DI viabiliza a colocação de papéis corporativos em prazos um pouco mais longos, mas fica com o risco de taxa de juros. Como pode ser visto no Gráfico 6, o prazo médio das debêntures indexadas a DI, ainda que superior a das LFTs, é ainda curto, variando de 4 a 6 anos, tendo melhorado nos últimos anos por conta de um cenário econômico mais benigno. Já as debêntures atreladas à inflação têm um prazo médio maior, mas tem tido uma oferta bem inferior, evidenciando as dificuldades de colocação desse tipo de papel.

\section{Gráfico 6 - Prazo médio dos títulos públicos federais e debêntures sem leasing (anos)}

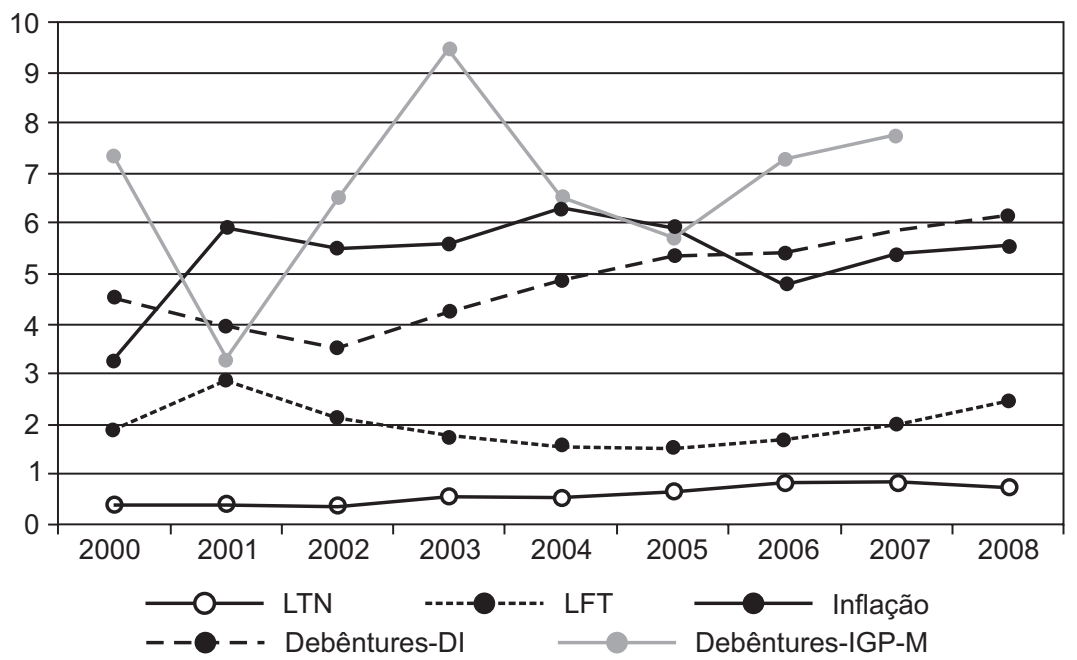

Fonte: Secretaria do Tesouro Nacional (2009).

\section{CARACTERÍSTICAS E EVOLUÇÃO DO MERCADO DE TÍTULOS DA DÍVIDA NO BRASIL PÓS-1994: UM BREVE PANORAMA GERAL}

Tendo como ponto de partida a evolução do contexto macroeconômico brasileiro, a evolução do MTD privada no Brasil pode ser dividido no pós-Real em quatro períodos: 1995/1998; 1999/2003; 2004/2007; e 2008.

No período 1995/1998, caracterizado pela operação de uma política econômica centrada em um câmbio semifixo, o volume médio de títulos corporativos de dívida (debêntures e notas promissórias) foi em média de cerca de $\mathrm{R} \$ 37$ bilhões anuais (valores de dezembro de 2008), bem superior a emissão primária de ações (R $\$ 14,4$ bilhões), de acordo com a Tabela 3. Esse período de câmbio semifixo e apreciado favoreceu também a captação de títulos no mercado externo, que teve o total de emissão média de US\$24,4 bilhões anuais no período, com destaque para notes e commercial papers de longo prazo. 
O período 1999/2003, de modo geral, é marcado pela instabilidade macroeconômica, com destaque para duas crises cambiais, uma no início de 1999 e outra ao final de 2002. Essa forte instabilidade macroeconômica afetou o comportamento tanto do mercado de títulos doméstico quanto externo, sendo que em determinados momentos o primeiro compensou a retração maior do segundo e, ainda, a forte contração na emissão de ações. Considerando todas as emissões de títulos e valores mobiliários corporativos no mercado doméstico a redução nas emissões foi bastante acentuada, passando de uma média de R \$ 52,3 bilhões em 1995/1998 para R \$ 35,7 bilhões em 1999/2003.

Cabe assinalar que a partir de 2002, no contexto da crise de confiança ante a iminência da eleição de Luís Inácio Lula da Silva para presidente, as tesourarias dos bancos fugiram parcialmente dos títulos de dívida pública, e passaram a carregar sua carteira com debêntures emitidas pelas Sociedades de Arrendamento Mercantil do próprio conglomerado financeiro, em operações compromissadas no mercado interbancário. Em uma operação conhecida como "Zé com Zé”, as empresas de leasing de um conglomerado financeiro emitiam debêntures da seguinte forma: beneficiados pelo fato de os recursos captados com esses títulos não serem passíveis de recolhimento compulsório, os bancos utilizavam suas empresas de leasings para emitir debêntures, sendo que os bancos ou os fundos de investimentos administrados por eles subscreviam tais debêntures, sendo que os recursos levantados retornavam as subsidiárias por meio de depósito interfinanceiro para servir de funding ao financiamento de veículos (Loureiro, 2008).

Tabela 3 - Emissões dos títulos e valores mobiliários

\begin{tabular}{l|l|l|l|l|l|l|c|c|c}
\hline Ações & Debêntures & $\begin{array}{c}\text { Notas } \\
\text { promissórias }\end{array}$ & CRI & $\begin{array}{c}\text { Quotas } \\
\text { de FIDC }\end{array}$ & $\begin{array}{c}\text { Quotas de } \\
\text { fundos de } \\
\text { invest. em } \\
\text { partip. }\end{array}$ & Total \\
\hline
\end{tabular}

Valores médios do período (R\$ milhões de dez/2008)*

\begin{tabular}{l|c|c|c|c|c|c|c|c|c}
\hline $1995 / 1998$ & $14.393,3$ & $24.339,3$ & 424,7 & $12.548,4$ & 0,0 & 0,0 & 0,0 & 526,1 & $52.231,8$ \\
\hline $1999 / 2003$ & $2.919,5$ & $19.251,8$ & 786,5 & $11.194,3$ & 295,9 & 494,0 & 35,4 & 768,9 & $35.746,4$ \\
\hline $2004 / 2007$ & $16.578,3$ & $49.690,6$ & 396,6 & $5.868,7$ & $1.339,8$ & $10.909,5$ & $8.830,5$ & 608,8 & $94.222,8$ \\
\hline 2008 & $32.658,5$ & $39.948,2$ & 531,3 & $26.382,0$ & 955,0 & $10.416,5$ & $20.574,4$ & 829,4 & $132.295,4$ \\
\hline \multicolumn{7}{|c|}{ Participação relativa (\%) } \\
\hline $1995 / 1998$ & 27,6 & 46,6 & 0,8 & 24,0 & 0,0 & 0,0 & 0,0 & 1,0 & 100,0 \\
\hline $1999 / 2003$ & 8,2 & 53,9 & 2,2 & 31,3 & 0,8 & 1,4 & 0,1 & 2,2 & 100,0 \\
\hline $2004 / 2007$ & 17,6 & 52,7 & 0,4 & 6,2 & 1,4 & 11,6 & 9,4 & 0,6 & 100,0 \\
\hline 2008 & 24,7 & 30,2 & 0,4 & 19,9 & 0,7 & 7,9 & 15,6 & 0,6 & 100,0 \\
\hline
\end{tabular}

Nota: ${ }^{*}$ ) Valores deflacionados pelo IGP-DI centrado.

Fonte: Elaboração própria com base em Comissão de Valores Mobiliários (2009). 
Já no período 2004/2007, marcado por contexto internacional benigno (liquidez internacional e boom de commodities), o crescimento do mercado de títulos doméstico foi bastante acentuado, com destaque para o crescimento na emissão de debêntures, ações e FIDC, este um instrumento de securitização criado ao final de 2002. Os FIDC são títulos de maturidade mais curtos (prazo médio de 2 a 3 anos) do que as debêntures, e predominantemente indexados a DI. Por serem títulos colateralizados em recebíveis e por poderem ser emitidos por empresas de capital fechado, acabam sendo alternativa preferencial de acesso ao mercado de capital por parte de pequenas e médias empresas. As emissões de títulos corporativos no mercado externo cresceram modestamente no período, com uma média de US\$22,9 bilhões anuais em 2004/2007 (contra US\$ 19,8 bilhões anuais em 1999/2003), em parte devido à diminuição de emissão de títulos públicos indexados ao câmbio, que fornecia um hedge contra o risco cambial.

Tabela 4 - Títulos de empresas brasileiras emitidos no exterior (US\$ milhões)

\begin{tabular}{l|c|c|c|c|c}
\hline Discriminação & $\begin{array}{c}\text { Ações de Cias. } \\
\text { brasileiras }\end{array}$ & $\begin{array}{c}\text { Bônus } \\
\text { de LP }\end{array}$ & $\begin{array}{c}\text { Notes } \\
\text { e commercial } \\
\text { papers de LP }\end{array}$ & $\begin{array}{c}\text { Títulos de rendas } \\
\text { fixa CP }\end{array}$ & $\begin{array}{c}\text { Total } \\
\text { de emissões }\end{array}$ \\
\hline $1995 / 1998$ & $4.582,8$ & $2.833,7$ & $16.855,0$ & 129,6 & $24.401,2$ \\
\hline $1999 / 2003$ & $3.676,1$ & $8.163,4$ & $6.528,8$ & $1.425,5$ & $19.793,8$ \\
\hline $2004 / 2007$ & $2.222,9$ & $6.719,0$ & $9.524,9$ & $4.435,7$ & $22.902,5$ \\
\hline 2008 & $4.842,3$ & 536,5 & $7.282,8$ & $3.557,6$ & $16.219,1$ \\
\hline & \multicolumn{5}{|c|}{ Participação relativa (\%) } \\
\hline $1995 / 1998$ & 18,8 & 11,6 & 69,1 & 0,5 & 100,0 \\
\hline $2004 / 2007$ & 18,6 & 41,2 & 33,0 & 7,2 & 100,0 \\
\hline 2008 & 9,7 & 29,3 & 41,6 & 19,4 & 100,0 \\
\hline
\end{tabular}

Fonte: Elaboração própria com base em Banco Central do Brasil (2009).

Por fim, o ano de 2008 é marcado pelo contágio da crise financeira internacional, que se fez sentir mais fortemente a partir de outubro de 2008. A grande maioria das debêntures no primeiro trimestre de 2008 corresponde às emissões de empresas de leasing, que abastecem os bancos (que não podem emitir debêntures) do mesmo conglomerado que buscavam recursos para ofertar mais crédito no mercado. Porém, a incidência do compulsório sobre os recursos repassados pelas empresas de leasing às instituições financeiras fez refluir bruscamente as emissões de debêntures por parte dessas empresas, e os bancos tiveram assim que captar recursos via emissão de CDBs, pagando relativamente mais caro $^{13}$. Assim, com redução da liquidez internacional

\footnotetext{
${ }^{13}$ Contudo, em janeiro de 2008, a Circular no 3.375 do Banco Central passou a cobrar dos bancos, de forma compulsória, parte do montante transferido das empresas de leasing para a tesouraria pela modalidade depósito interfinanceiro. Essa norma praticamente estancou o lançamento de debêntures de leasing.
} 
devido ao aumento da aversão ao risco provocado pela crise do subprime, os CDBs aumentaram fortemente a concorrência com as debêntures pela poupança doméstica, sendo que os bancos chegaram a pagar mais de 107\% do CDI para captar com CDB. Além disso, a elevação da taxa Selic no primeiro semestre de 2008 exigiu retornos maiores das debêntures. A partir daí os investidores passaram a exigir altas taxas e prazos curtos. Tudo isso fez com que as emissões de debêntures caíssem drasticamente a partir do segundo trimestre de 2008, com participação de 2,8\%, 10,2\% e 3\% do total de emissões privadas nos três trimestres subsequentes. A contração desses papéis foi parcialmente compensada pela emissão de notas promissórias ${ }^{14}$ a partir do segundo trimestre de 2008, perfazendo $26,4 \%$ do total de emissões de títulos privados nesse trimestre, e 15,9\% e 53,2\% no terceiro e quarto trimestre de 2008. Quanto à emissão externa, há forte queda ao longo do ano de 2008 em função da crise financeira internacional e a aversão ao risco que a seguiu: as "Notes e commercial papers de longo prazo" a partir do segundo trimestre de 2008 e os títulos de renda fixa de curto prazo caem fortemente a partir do primeiro trimestre de 2008.

Os principais demandantes de títulos corporativos no Brasil têm sido os fundos de investimento e os fundos de pensão. Há uma grande sobreposição entre as aplicações destes dois agentes institucionais, uma vez que uma boa parte das aplicações dos fundos de pensão é feito através de fundos de investimento. A Tabela 5 mostra uma maior diversificação na indústria de fundos, com uma diminuição ao longo do tempo do peso dos fundos de renda fixa e DI e crescimento em contrapartida dos fundos multimercado, fundos de ações e previdência, ainda que se mantenha a predominância dos fundos de renda fixa e fundos DI, responsáveis por $45 \%$ do total do patrimônio líquido dos fundos em dezembro de 2007. A mobilização de recursos pelos fundos atinge o seu ápice em 2007, com cerca de R\$ 1,4 trilhões (valores de dezembro de 2008).

No que se refere à composição de carteiras dos fundos de investimento predominam as aplicações em títulos públicos federais, que representavam $76,1 \%$ das aplicações em 2000, caindo para 41,4\% em 2008, sendo que parte migra para operações compromissadas lastreadas em títulos públicos. No que tange as aplicações em títulos privados destacam-se as ações, que atingem 21,7\% das aplicações em 2007, e CDBs (mais de 10\% das aplicações a partir de 2005). As aplicações em debêntures são mais modestas, representando em geral 3\% a 4\% do total das aplicações dos fundos. De todo modo, as aplicações em títulos públicos federais, somadas as operações compromissadas perfaziam $60,5 \%$ do total das aplicações. As aplicações em ações e debêntures juntas, por sua, representaram apenas cerca de $15 \%$ a $20 \%$ do total no período 2000/2008.

\footnotetext{
${ }^{14}$ Notas promissórias são títulos corporativos em curto prazo (30 a 360 dias, no máximo).
} 


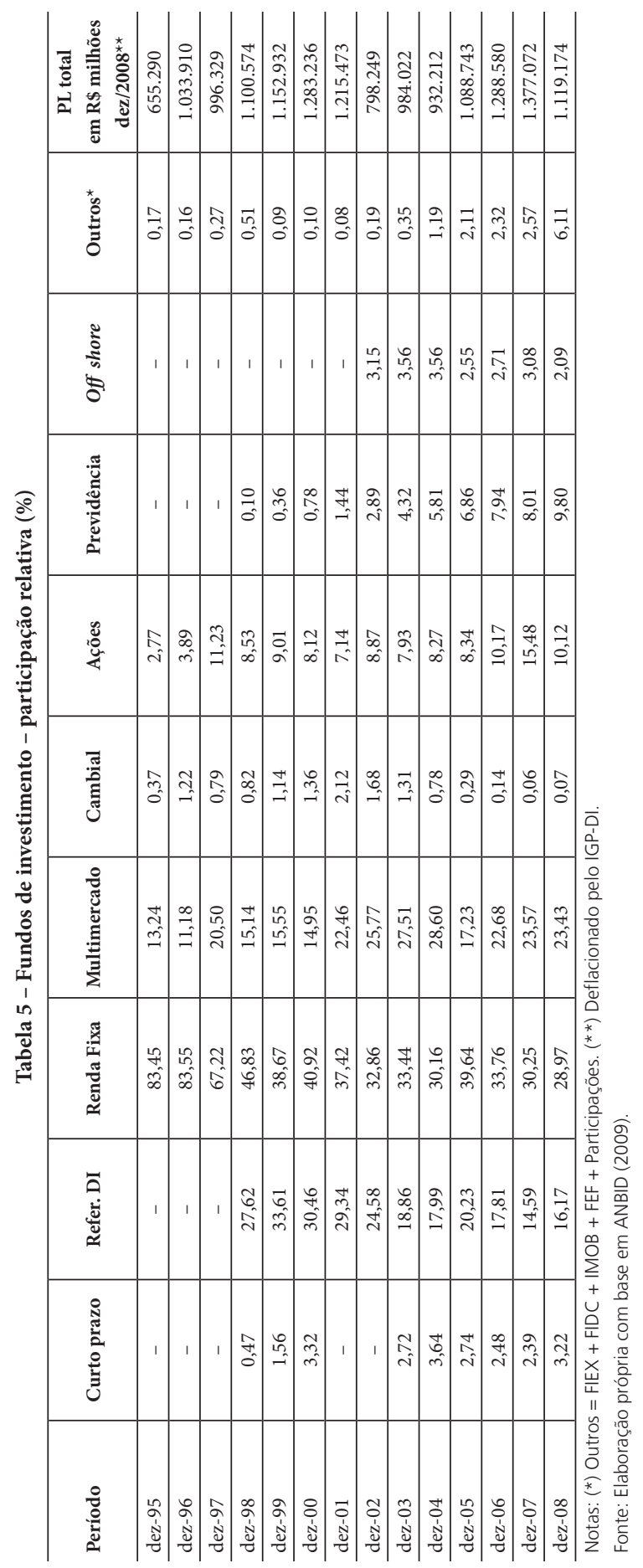


Tabela 6 - Fundos de Investimento: composição da carteira (\%)

\begin{tabular}{|c|c|c|c|c|c|c|c|}
\hline & $\begin{array}{c}\text { Operações } \\
\text { Compromis.** }\end{array}$ & $\begin{array}{l}\text { Tit. publ. } \\
\text { federais }\end{array}$ & CDB e RDB & Debêntures & Ações & Outros & Total \\
\hline $\mathrm{dez} / 00$ & - & 76,14 & 4,52 & 2,89 & 11,11 & 5,35 & 100,00 \\
\hline $\mathrm{dez} / 01$ & - & 75,16 & 7,65 & 4,41 & 9,52 & 3,26 & 100,00 \\
\hline dez/03 & - & 75,86 & 6,77 & 3,82 & 10,33 & 3,22 & 100,00 \\
\hline $\mathrm{dez} / 04$ & 13,23 & 58,99 & 8,44 & 2,80 & 11,17 & 5,36 & 100,00 \\
\hline $\mathrm{dez} / 05$ & 9,43 & 60,53 & 10,66 & 3,93 & 11,16 & 4,30 & 100,00 \\
\hline $\mathrm{dez} / 08$ & 19,10 & 41,46 & 13,70 & 4,44 & 14,45 & 6,86 & 100,00 \\
\hline
\end{tabular}

Notas: Dados do Ranking Global de Administração de Recursos de Terceiros.

${ }^{*}$ ) Lastro em títulos públicos e privados.

Fonte: Elaboração própria com base em ANBID (2009).

Como já assinalado, a emissão primária de debêntures teve um forte boom em 2005/2007, ainda que este crescimento tenha sido em parte puxado pelas emissões de empresas de leasing, do qual uma boa parte foi canalizada para servir de funding para financiamento de veículos. Excluindo as debêntures-leasing o boom de debêntures nesse período seria bem mais modesto, como pode ser visto no Gráfico 7 .

\section{Gráfico 7 - Volume de emissão de debêntures (R\$ bilhões em dez/2008)}

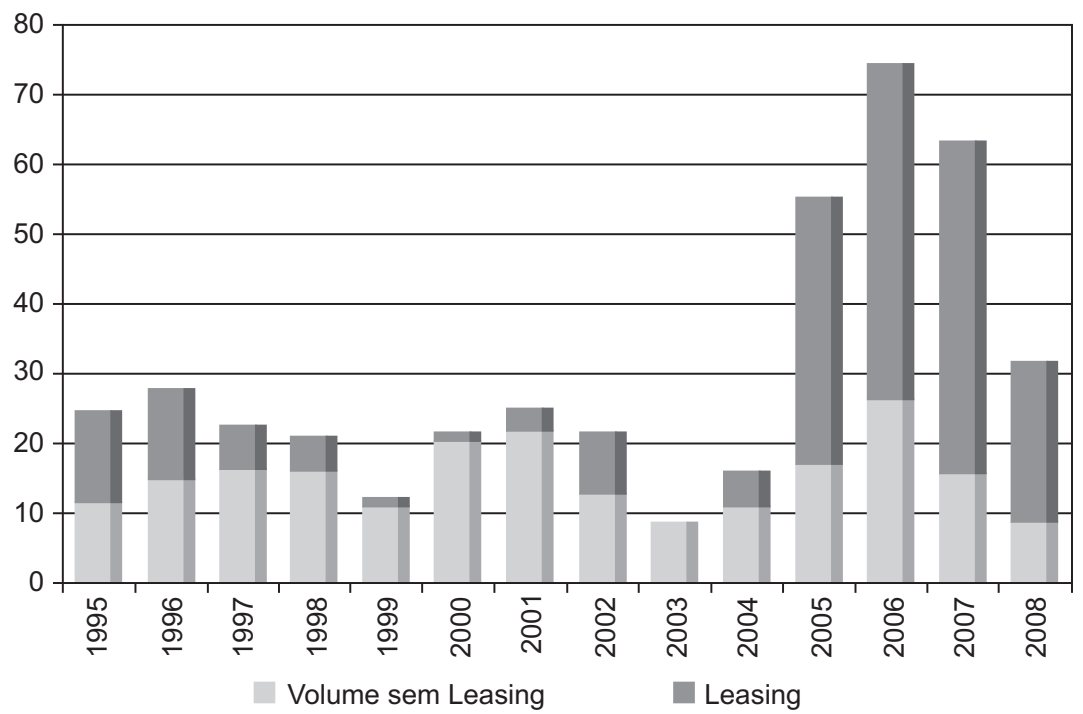

Fonte: Elaboração própria com base em Sistema Nacional de Debêntures (2009). 
Quanto ao tipo de garantia, há uma clara predominância de debêntures com menor garantia, em particular as debêntures subordinadas e as quirográficas. As primeiras oferecem preferência tão somente sobre o crédito dos acionistas, enquanto que as segundas não oferecem privilégio algum sobre o ativo da empresa. Tais preferências parecem expressar o fato de que como o mercado de debêntures é operado por um conjunto pequeno de empresas e capital aberto de boa reputação no mercado não há necessidade de maiores garantias, como no caso de garantia flutuante ou garantia real. $\mathrm{O}$ uso de tais garantias implicaria que o demandante teria que aceitar um prêmio de risco menor na remuneração de tais papéis.

No que tange ao prazo médio de emissão de debêntures, ocorre uma acentuada melhoria a partir de 2004, passando de um prazo de cerca de 5 anos para mais de 7 anos, sendo tal crescimento um pouco mais modesto quando se considera apenas as debêntures não leasing.

Gráfico 8 - Debêntures por tipo de garantia (\% do total)

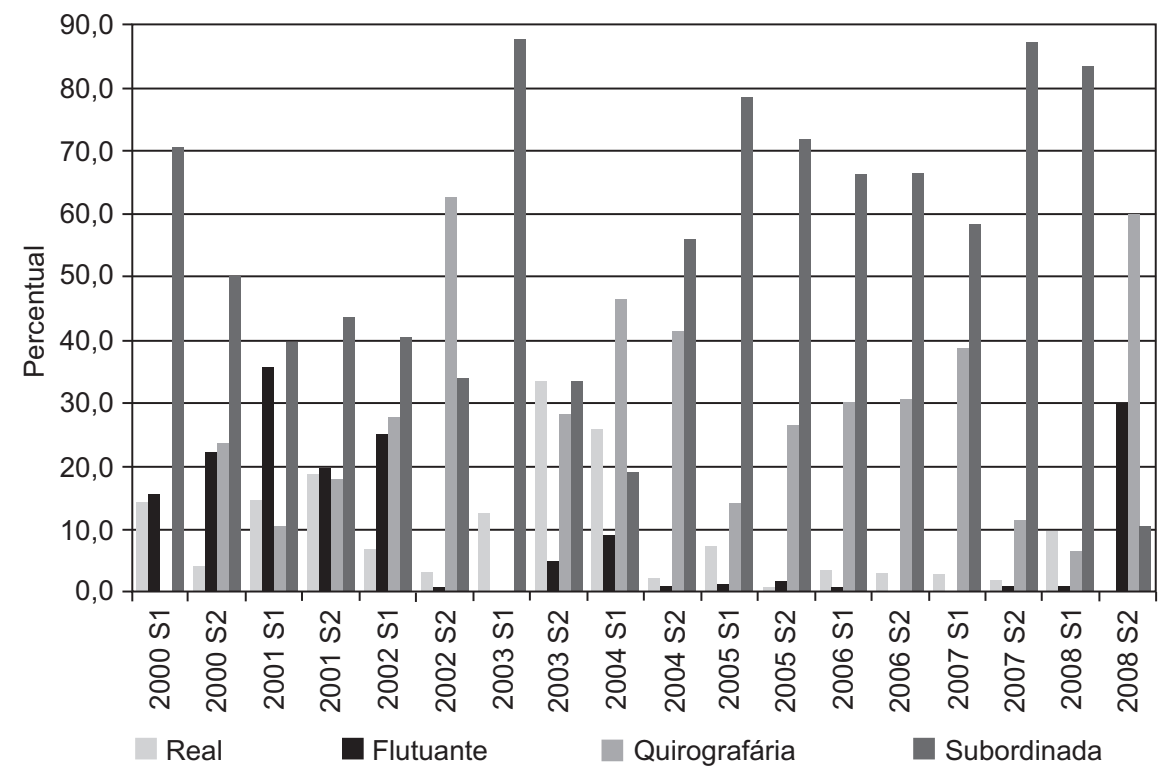

Fonte: Elaboração própria com base em Sistema Nacional de Debêntures (2009). 


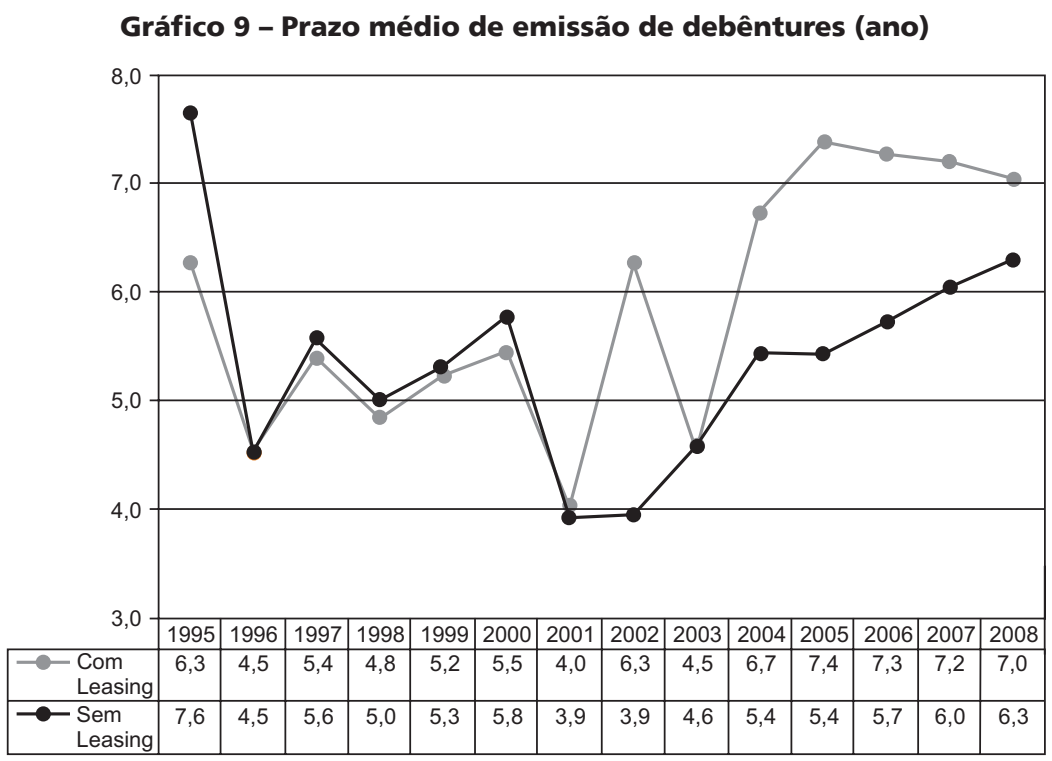

Fonte: Elaboração própria com base em Sistema Nacional de Debêntures (2009).

Quando se compara a taxa DI, que remunera a maior parte das debêntures ${ }^{15} \mathrm{e}$ FIDCs emitidas, com a taxa de empréstimos cobrada no financiamento de capital de giro das empresas observa-se um diferencial significativo, superior a 15 pontos percentuais (Gráfico 10). Isso evidencia que o custo do financiamento na emissão de debêntures é bem menor do que o custo do crédito bancário. Contudo, deve-se considerar que o mercado de debêntures é acessível apenas a empresas de capital aberto e que o custo de emissão (road shows, custos de corretagem para o banco coordenador da emissão e ao agente fiduciário etc.) é relativamente elevado, o que requer uma "escala mínima" de emissão para diluir tais custos. Ademais, o crédito bancário é bem mais ágil para obtenção dos recursos e o montante pode ser melhor moldado as necessidades do demandante.

Considera-se ainda que a demanda por debêntures é limitada por sua falta de liquidez, pela quase inexistência de um mercado secundário organizado, que estimularia a demanda por papéis da maturidade mais longa. Como poder ser visto na Tabela 7 o mercado secundário de debêntures é bem modesto quando comparado ao mercado de ações. De modo a compensar a baixa liquidez desses papéis, os emissores de debêntures são impelidos a emitir papéis com prazos ainda poucos dilatados.

\footnotetext{
${ }^{15} \mathrm{O}$ percentual de debêntures indexadas a taxa DI, que é permitida a partir de 1999, é de mais de $65 \%$ a partir de 2000, atingindo mais de 90\% das debêntures emitidas a partir de 2005.
} 


\section{Gráfico 10 - Taxa de juros para pessoa jurídica (\%)}

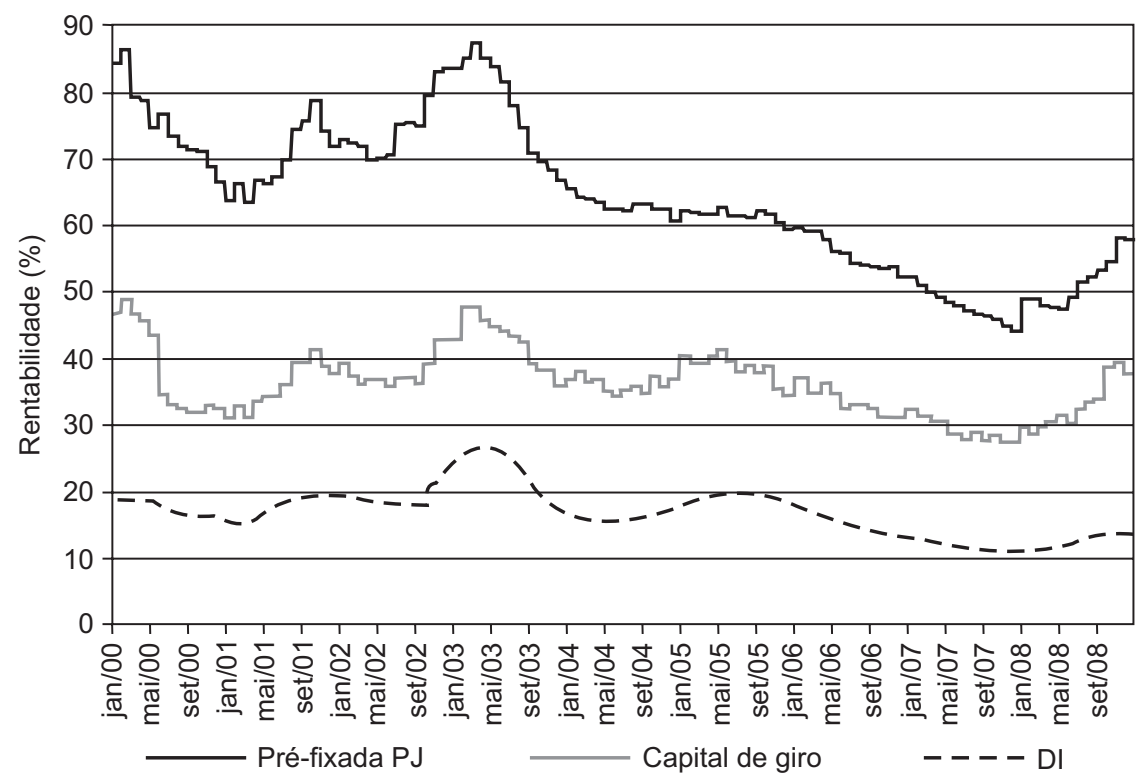

Fonte: Banco Central do Brasil (2009).

Tabela 7 - Participação no mercado secundário (em \%)*

\begin{tabular}{l|c|c|c|c|c|c|c}
\hline & SND & $\%$ & BovespaFix & $\%$ & Ações & $\%$ & Total \\
\hline 1995 & $55.294,8$ & 20,2 & 0,00 & 0,0 & $217.767,02$ & 79,8 & $273.061,77$ \\
\hline 1996 & $191.278,7$ & 38,7 & 0,00 & 0,0 & $302.815,62$ & 61,3 & $494.094,33$ \\
\hline 1997 & $94.697,6$ & 12,3 & 0,00 & 0,0 & $672.396,73$ & 87,7 & $767.094,37$ \\
\hline 1998 & $20.723,1$ & 3,6 & 0,00 & 0,0 & $553.732,18$ & 96,4 & $574.455,25$ \\
\hline 1999 & $30.236,4$ & 7,0 & 0,00 & 0,0 & $404.791,89$ & 93,0 & $435.028,32$ \\
\hline 2000 & $28.845,9$ & 6,5 & 0,00 & 0,0 & $416.310,50$ & 93,5 & $445.156,41$ \\
\hline 2001 & $34.381,1$ & 10,4 & 79,65 & 0,0 & $296.820,09$ & 89,6 & $331.280,80$ \\
\hline 2002 & $36.920,0$ & 13,2 & 568,99 & 0,2 & $241.452,23$ & 86,6 & $278.941,27$ \\
\hline 2003 & $33.584,1$ & 10,4 & 557,53 & 0,2 & $288.604,12$ & 89,4 & $322.745,72$ \\
\hline 2004 & $18.242,4$ & 4,4 & $1.769,16$ & 0,4 & $392.356,53$ & 95,1 & $412.368,07$ \\
\hline 2005 & $23.443,1$ & 4,6 & 396,20 & 0,1 & $490.340,37$ & 95,4 & $514.179,71$ \\
\hline 2006 & $17.793,2$ & 2,4 & 133,22 & 0,0 & $718.809,26$ & 97,6 & $736.735,71$ \\
\hline 2007 & $31.140,9$ & 2,2 & 151,22 & 0,0 & $1.362 .285,88$ & 97,8 & $1.393 .577,99$ \\
\hline 2008 & $66.365,5$ & 4,5 & 106,97 & 0,0 & $1.414 .581,30$ & 95,5 & $1.481 .053,76$ \\
\hline
\end{tabular}

*Nota: valores em R\$ milhões de dezembro de 2008, deflacionados pelo IGP-DI centrado.

Fonte: Elaboração própria com base em Comissão de Valores Mobiliários (2009). 
Vários problemas têm sido apontados para explicar a inibição do mercado secundário de debêntures, entre eles cabem destacar: a baixa padronização das debêntures, o que faz com que sua baixa "substitubilidade" dificulte a devida precificação desses papéis; existência de relativamente poucos emissores de debêntures - como pode ser visto no Gráfico 11 os oito maiores emissores responderam por $53 \%$ do valor das emissões em 2004/2008 ${ }^{16}$; distribuição desses papéis geralmente concentrada em poucos investidores de grande porte - fundos de investimento e fundos de pensão.

\section{Gráfico 11 - Maiores emissores de debêntures: 2004/2008 (\% do total)}

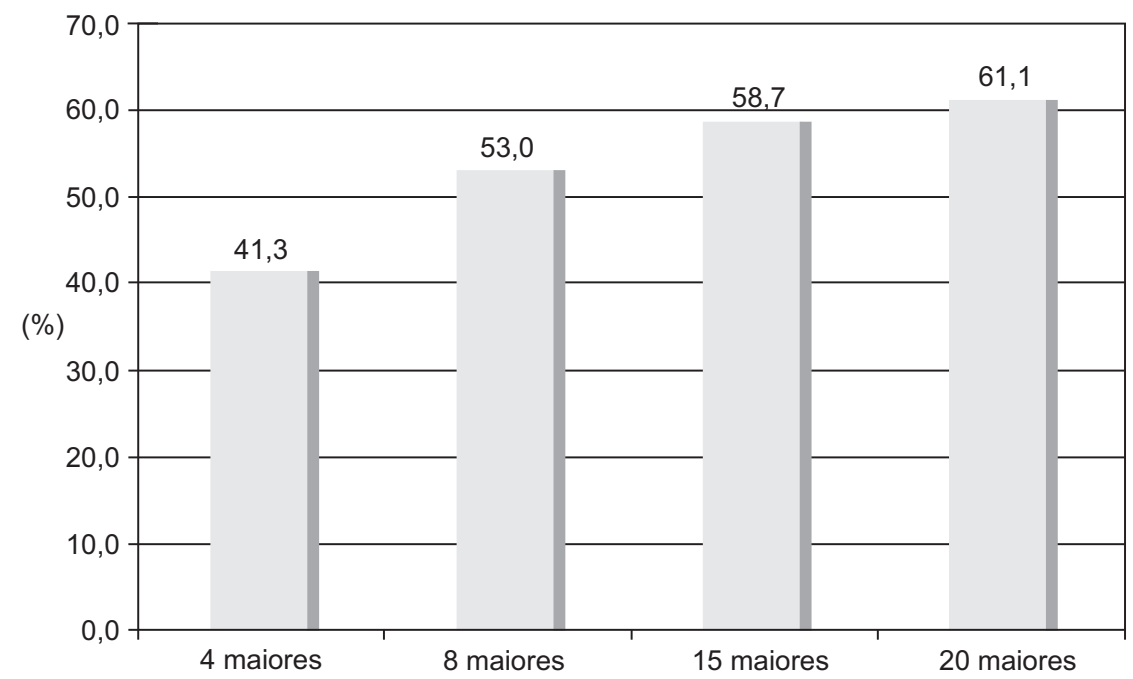

Fonte: Elaboração própria com base em Sistema Nacional de Debêntures (2009).

Moura (2006, p. 250) aponta um ponto adicional relacionado com as LFTs: a pouca variabilidade do preço desses papéis desestimula sua negociação no mercado secundário, dificultando a formação de uma estrutura a termo da taxa de juros. $\mathrm{O}$ giro das LFTs no mercado secundário são inferiores ao das LTNs, que por terem seu preço variável de acordo com as mudanças nas taxas de juros são mais adequados para serem negociados no mercado de revenda de títulos. Esse ponto é importante para nossa discussão, uma vez que o desenvolvimento do mercado secundário de títulos públicos estimula, ceteris paribus, o desenvolvimento do mercado de títulos

\footnotetext{
${ }^{16}$ Os oito maiores emissores de debêntures em 2004-2008 foram: BFB Leasing, BV Leasing, Bradesco Leasing, Dibens Leasing, Real Leasing, ABN Amro Leasing, Itaubank Leasing e Vale Leasing; portanto, a grande maioria era constituída de Sociedade de Arrendamento Mercantil.
} 
privados. Moura (2006, p. 252) conclui que as LFTs substituem e tornam redundante a existência de um vigoroso mercado secundário. O Gráfico 12 mostra a evolução do total negociado no mercado secundário de títulos públicos (operações definitivas) e o volume de títulos públicos federais excetuando as LFTs no período 2000 a 2008. Como já destacado a partir de meados de 2003 há uma redução no estoque das LFTs e crescimento dos títulos prefixados e, em menor grau, dos títulos indexados a inflação. O que o gráfico sugere é que tal mudança não teve maiores efeitos sobre o mercado secundário de títulos públicos, como seria de se esperar a partir da argumentação de Moura (2006). Tal relação, portanto, deve ser mais bem aprofundada.

\section{Gráfico 12 - Mercado secundário de títulos públicos e estoque de títulos públicos sem LFTs (R\$ milhões de dez/2008)}

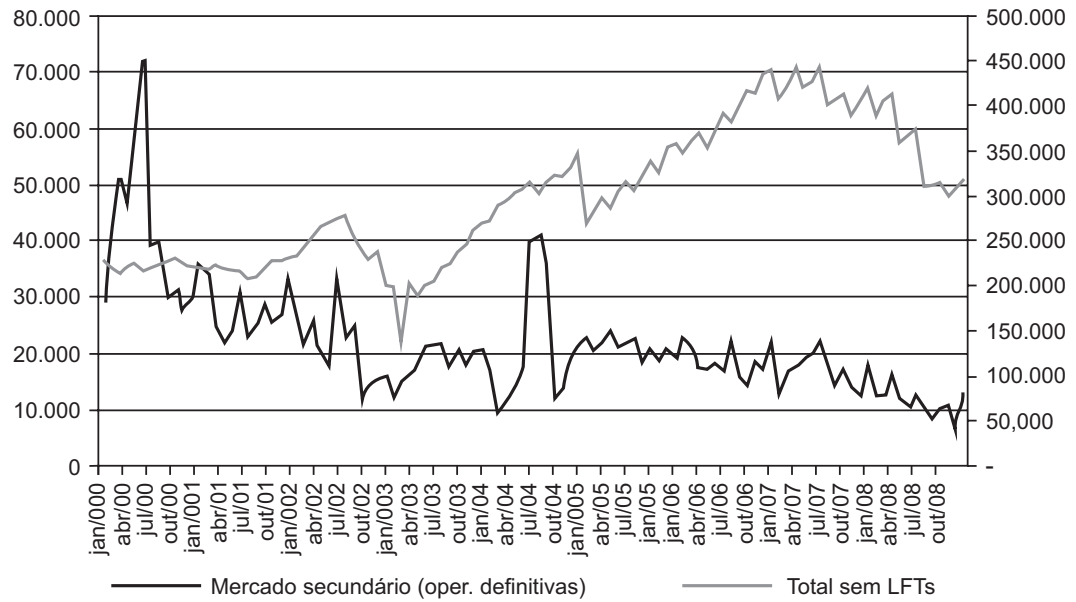

Fonte: Secretaria do Tesouro Nacional (2009).

\section{CONCLUSÕES E PERSPECTIVAS}

$\mathrm{Na}$ análise feita sobre o MTD privada no Brasil mostrou-se os impactos do ambiente macroinstitucional sobre a evolução recente desse mercado. Em particular, as condições de instabilidade macroeconômica de uma economia em stop and go que caracterizou o país na última e presente década têm afetado o volume e as condições de emissão primária de títulos de dívida privada no Brasil, ao aumentar o risco de mercado (perda de valor de um título perante a uma elevação da taxa de juros) e o risco de inadimplência na emissão de tais títulos, em particular no caso de títulos corporativos de renda fixa. De fato, o histórico de instabilidade macroeconômica que marcou a economia brasileira desde os anos 1980 é o fator principal na formação do perfil de dívida de curto prazo e com parcela significativa constituída por títulos atrelados à taxa Selic e a DI. 
Ademais, mostrou-se não haver complementaridade entre o mercado de dívida pública e o mercado de dívida privada no Brasil, mas sim a existência de uma concorrência entre os eles. De fato, em que pese o elevado desenvolvimento do mercado de títulos públicos, a existência de uma boa parte da dívida pública sob a forma de títulos indexados a Selic (LFTs), herança do período de alta inflação, acaba por inibir e deformar o MTD privada no Brasil, uma vez que a combinação risco-retorno dos títulos públicos é uma das melhores entre os ativos financeiros, por combinar baixo risco, alta liquidez e rentabilidade. Isso resulta em uma alta demanda por aplicações nos chamados fundos de depósitos interbancários (DI) ou diretamente por títulos públicos federais. Portanto, a forma de gestão da dívida pública no Brasil acaba sendo determinante nas "preferências" do investidor, ao moldar uma combinação risco-retorno que privilegia aplicações indexadas a taxa Selic e sua "prima" a taxa DI ou aplicações de renda fixa de curto prazo.

Ao se analisar as perspectivas futuras do mercado de título de dívida (MTD) privada devem-se considerar três dimensões de certa forma interconectadas: a evolução do contexto macroeconômico, o contexto regulatório e a gestão da dívida pública.

A primeira dimensão - contexto macroeconômico - é importante uma vez que o mercado decapitais no Brasil tem tido um comportamento pró-cíclico, desenvolvendo-se em períodos de maior crescimento e estabilidade, e contraindo em períodos de desaceleração cíclica e instabilidade macroeconômica. Como já foi assinalado, uma das características da economia brasileira tem sido seu comportamento stop and go e uma tendência a um baixo crescimento. $\mathrm{O}$ ambiente de instabilidade macroeconômica afeta o volume e as condições de emissão primária de títulos de dívida privada no Brasil, ao aumentar o risco de mercado (perda de valor de um título perante a uma elevação na taxa de juros) e o risco de inadimplência. Expectativas altistas quanto à taxa de juros elevam o prêmio exigido pelos demandantes por títulos de maturidade mais longa e aumentam a demanda por títulos indexados ao DI (o que coloca nas mãos da firma o problema do risco de taxa de juros). Portanto, tanto a volatilidade quanto o nível da taxa de juros afetam decisivamente as condições de oferta e demanda de títulos corporativos no Brasil. Por exemplo, uma taxa de juros mais baixa e estável pode estimular a demanda por títulos de dívida prefixados, mais adequados do ponto de vista da redução da fragilidade financeira das firmas.

O boom do mercado de capitais no período 2004-2007 mostrou como um ambiente econômico mais favorável acaba estimulando o desenvolvimento do mercado de títulos de dívida e de capitais em geral: não só o volume de emissão de títulos de dívida privada cresceu, como se propiciou um alongamento em seus prazos. É importante assinalar que o mercado de capitais é estimulado pelo, e estimula o, crescimento econômico, ou seja, é causa e efeito, já que cumpre um papel importante do ponto de vista do financiamento das empresas de médio e grande porte. Apesar do autofinanciamento via lucros retidos ser a principal forma de financiamento dos investimentos e da produção no Brasil, as firmas tendem a buscar - em um segundo momento por 
ocasião de um processo de crescimento econômico mais sustentável - recursos externos a firma por ocasião da expansão de sua atividade produtiva. Assim, a gestão de uma política macroeconômica estabilizadora - viabilizando taxas de juros mais baixas e estáveis e estimulando o crescimento da demanda agregada na economia (e aumentando consequentemente os lucros das empresas) - tem um papel fundamental no crescimento mais robusto do mercado de títulos de dívida no Brasil. Trata-se de uma condição necessária, ainda que possa não ser suficiente, para o desenvolvimento deste mercado. A redução da taxa de juros ocorrida a partir do segundo semestre de 2011 estimulou, na margem, a diversificação de portfólio dos investidores - em particular dos investidores institucionais como fundos de pensão, fundos de investimento e seguradoras - para absorver títulos de maior risco em relação a títulos públicos, uma tendência que se confirmada e continuada deverá ter efeitos positivos importantes para o desenvolvimento do mercado de títulos corporativo privado no Brasil.

Mudanças regulatórias que estimulem o mercado de títulos de dívida - por parte das autoridades regulatórias (CVM) e autorregulatórias (ANBIMA) - são importantes tanto do ponto de vista do mercado primário de títulos de dívida (como, por exemplo, medidas que busquem a simplificação das emissões e sua popularização, estimulando o aumento de demandantes desses títulos), quanto do ponto de vista da expansão de mercados secundários, através de medidas que estimulem a revenda de títulos. Por exemplo, pode-se considerar medidas que ajudem a criação de uma curva de rendimentos de títulos de dívida privado, como é o caso da "publicização" do cálculo de preços indicativos de debêntures por parte da ANBIMA, visando tornar comparáveis os rendimentos de títulos privados com maturidades semelhantes. Uma agenda interessante para discussão seria identificar medidas poderiam ser adotadas para "popularizar" a oferta de títulos nos bancos varejistas, através de fundos específicos lastreados com esses papéis. Nesse sentido, os bancos públicos varejistas poderiam ajudar, por exemplo, diminuindo o "ticket de entrada", isto é, o valor mínimo de aplicação em títulos corporativos.

Ainda do ponto de vista regulatório, uma importante medida a ser adotada é a implementação de tributação que estimule a aplicação de recursos mais de longo prazo. Na legislação atual, a tributação do imposto de renda (IR) incide nos fundos de curto prazo com uma alíquota de $22,5 \%$ sobre os rendimentos até 180 dias e $20 \%$ acima de 180 dias, enquanto que nos fundos de longo prazo e títulos de renda fixa 22,5\% até 180 dias, $20 \%$ de 181 a 360 dias, 17,5\% de 361 a 720 dias, e 15\% acima de 720 dias. Nesse particular, sugere-se uma tributação regressiva mais efetiva do ponto de vista do estimulo ao alongamento dos prazos dos títulos de dívida, através da cobrança de imposto ainda mais alto para investimentos de curto prazo (por exemplo, aumentando a alíquota para $30 \%$ até 180 dias), reduzindo a alíquota conforme o prazo de aplicação.

Por último, mas não menos importante, mudanças no perfil da dívida pública podem exercer um papel crucial no desenvolvimento do mercado de títulos de dívida privada no Brasil, tanto no que se refere ao mercado primário quanto ao mercado 
secundário. A existência de títulos indexados à Selic acaba funcionando com um fator inibidor tanto do mercado primário de títulos privados, por conta da competição de um papel livre de risco de mercado e risco de default, quanto do mercado secundário de títulos, uma vez que a prevalência de tais títulos (indexados à Selic) desestimula o desenvolvimento do mercado secundário de títulos públicos (que poderia, por sua vez, fomentar o desenvolvimento do mercado secundário de títulos privados). De fato, o que estimula a atuação do investidor-especulador nesse mercado é justamente a possibilidade de especular em relação às variações do valor do título. Nesse sentido, observa-se uma melhoria no perfil da dívida pública em 2004-2007, passando os títulos prefixados de $16,8 \%$ do total em junho de 2004 para $37,3 \%$ em dezembro de 2007, mas caindo ao longo de 2008 e 2009 no quadro do contágio da crise financeira internacional, e voltando a crescer ao longo de 2010 (37,9\% em dezembro). Portanto, a melhoria no perfil da dívida pública, com diminuição de títulos indexados à Selic e crescimento de títulos prefixados, que pode ser propiciada pela queda na taxa de juros de curto prazo e melhoria no contexto macroeconômico em geral ${ }^{17}$, terá efeitos benéficos tanto do ponto de vista do desenvolvimento do mercado primário (dada à contaminação dos títulos privados por títulos públicos indexados à Selic) quanto do mercado secundário, já que se espera que o desenvolvimento do mercado secundário de títulos públicos ajude a fomentar o mercado secundário de títulos privados ${ }^{18}$.

\footnotetext{
${ }^{17} \mathrm{~A}$ ideia subjacente é que uma taxa de juros mais baixa e mais estável diminui a demanda por hedge contra o risco de taxa de juros, que como visto a LFT proporciona, aumentando consequentemente a demanda por títulos prefixados.

${ }^{18}$ O governo federal, em dezembro de 2010, aproveitou o ciclo de crescimento da economia brasileira para introduzir medidas para estimular o desenvolvimento do mercado de títulos de renda fixa (debêntures), enfrentando alguns problemas aqui colocados. Para tanto, procura estimular a demanda por tais títulos com maturidade mais longa, ao estabelecer alíquota zero do imposto de renda para pessoa física (15\% para pessoa jurídica) e investidores estrangeiros para debêntures de duration mínima de 4 anos para projetos de infraestrutura, além de alíquota zero para aplicação de não residentes em debêntures com rendimento por taxa prefixada ou índice de preços; para estimular a liquidez do mercado de títulos privados, foi eliminado o IOF de até 30 dias sobre compra e venda desses títulos, e autorizado que instituições financeiras destinem até $3 \%$ do compulsório sobre depósitos a prazo para criação de um fundo de liquidez. O BNDES, por sua vez, adotou medidas complementares para estimular este mercado: um programa de aquisição primária de debêntures com dotação de $\mathrm{R} \$ 10$ bilhões para compra de títulos não indexados a DI, participação no fundo de liquidez de títulos privados com aporte até $\mathrm{R} \$ 200$ milhões, e permissão dada para o banco alugar suas debêntures em carteira para formadores de mercados de modo ampliar a liquidez dos papéis negociados. Essas medidas parecem ir na direção correta de buscar estimular os investidores a aumentarem sua demanda por debêntures, tornando-os mais atrativos, e com indexadores e prazos mais adequados para as empresas; contudo, para serem eficazes devem ser acompanhadas por mudanças no contexto macroeconômico, em particular com uma redução na taxa de juros e uma redução maior no estoque de LFTs.
} 


\section{REFERÊNCIAS}

ANBID. www.anbid.com.br, acesso em agosto de 2009.

BCB. Banco Central do Brasil. www.bcb.gov.br, acesso em agosto de 2009.

CARVALHO, F.C. Sobre a preferência pela liquidez dos bancos. In: PAULA, L.F.; OREIRO, J.L. (orgs.). Sistema Financeiro: uma análise do setor bancário brasileiro. Rio de Janeiro: Campus/Elsevier, 2007.

CARVALHO, F.C.; SOUZA, F.E.P.; SICSÚ, J.; PAULA, L.F.; STUDART, R. Economia Monetária e Financeira. 2. ed. Rio de Janeiro: Campus/Elsevier, 2007.

CARVALHAL DA SILVA, A.L.; LEAL, R.P. O mercado de títulos privados de renda fixa. Rio de Janeiro: ANDIMA, 2008.

CETIP. www.cetip.com.br, acesso em agosto de 2009.

CVM. Comissão de Valores Mobiliários, http://www.cvm.gov.br, acesso em setembro de 2009.

FERREIRA, C.K.L.; ROBOTTON, M.F.; DUPITA, A.B. Política monetária e alongamento da dívida pública: uma proposta de discussão. Texto para Discussão, PUC-SP, n. 9, 2004.

FRANCO, G. Notas sobre o crowding out, juros altos e Letras Financeiras do Tesouro. In: BACHA, E.L.; OLIVEIRA LIMA, L.C. (orgs.). Mercado de capitais e divida pública: tributação, indexação, alongamento. Rio de Janeiro: Contracapa, 2006.

HERMANN, J. Financiamento de longo prazo: revisão do debate e propostas para o Brasil. In: SICSÚ, J.; OREIRO, J.L.; PAULA, L.F. (orgs.). Agenda Brasil: políticas econômicas para o crescimento com estabilidade de preços. Rio de Janeiro: Manole, 2003.

IMF. International Financial Statistics. Washington: IMF, 2009.

IPEADATA, http://www.ipeadata.gov.br, acesso em agosto de 2009.

LOUREIRO, M. Mudança nas regras do compulsório tira as leasings de cena no mercado de debêntures. Revista Capital Aberto, p. 110-13, maio 2008.

MODENESI, A. Convenção e rigidez na política monetária: uma estimativa da função de reação do BCB - 2000-2007. Texto para Discussão, IPEA, n. 1.351, 2008.

MOURA, A. Letras financeiras do Tesouro: quousque tandem? In: BACHA, E.L.; OLIVEIRA LIMA, L.C. (orgs.). Mercado de capitais e dívida pública: tributação, indexação, alongamento. Rio de Janeiro: Contracapa, 2006.

PAULA, L.F. Dinâmica da firma bancária: uma abordagem não-convencional. Revista Brasileira de Economia, v. 53, n. 3, p. 323-356, 1999.

SISTEMA NACIONAL DE DEBÊNTURES, www.debêntures.com.br, acesso em agosto de 2009.

SNT. Secretaria Nacional do Tesouro, http://www.tesouro.fazenda.gov.br, acesso em agosto de 2009. 


\section{ANEXO I DURATION DE UM TÍTULO DE RENDA FIXA}

A duration de um título de renda fixa é uma medida do tempo necessário para que o detentor do título possa reaplicar o capital (principal mais juros) aplicado no título à nova taxa de juros praticada no mercado, ou seja, o tempo que o capital retorna ao investidor para que este possa se reposicionar na nova taxa de juros de mercado.

Por exemplo, um título prefixado e sem cupom, como é o caso de uma LTN, terá duration igual ao seu prazo de vencimento. Um investidor que aplicar R $\$ 1.000,00$ em um título que paga $10 \%$ a.a. com recebimento de principal e juros após o prazo de cinco anos, receberá no vencimento $\mathrm{R} \$ 1.610,51$, quando então poderá reaplicá-los à nova taxa de juros de mercado. Desta forma, o investidor só poderá se reposicionar na taxa de juros após o prazo de cinco anos.

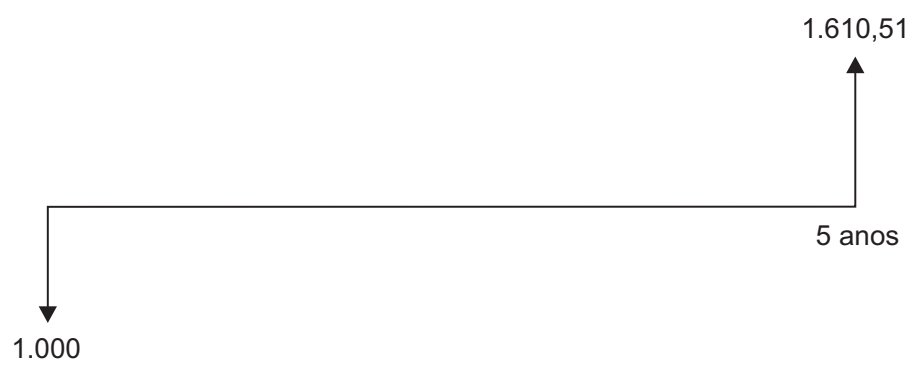

Para o caso do título do exemplo acima pagar cupons de juros semestrais, a duration será menor que o prazo do título. Dado que o investidor receberá valores antes do vencimento do título (cinco anos), estes valores recebidos antes do vencimento ( $R$ \$ 50,00 reais a cada semestre) podem ser reaplicados a nova taxa de juros de mercado, antes do prazo de cinco anos, ou seja, o tempo necessário para o investidor se reposicionar na taxa de juros será menor que o prazo do título, que é de cinco anos. Desta forma, a duration representa uma média ponderada do tempo em que se espera receber os juros mais o principal de uma operação. Segundo Van Horne, a equação da duration é:

$$
D=\frac{\sum_{t=1}^{n}\left[\frac{F C_{t}}{(1+R)^{t}} * t\right]}{\sum_{t=1}^{n}\left[\frac{F C_{t}}{(1+R)^{t}}\right]}
$$


Para o exemplo, a duration será de quatro anos, enquanto o seu prazo é de cinco anos.

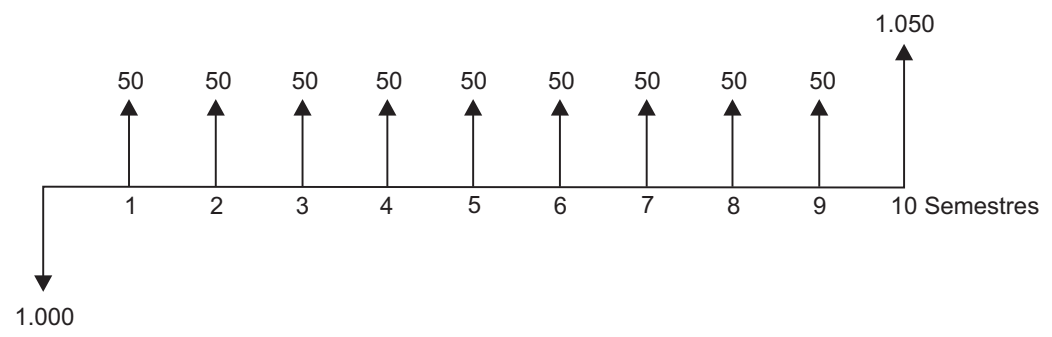

Para um título pós-fixado indexado a Selic, a duration será de um dia, ou duration zero, dado que o título remunera o valor aplicado pela taxa de juros de cada dia, é como se o investidor estivesse a cada dia (durante todo o prazo do título) reaplicando o principal e o juro ganho à nova taxa de juros de mercado. 